\title{
The Distribution of Submersed Aquatic Vegetation and Water Lettuce in the Fresh and Oligohaline Tidal Potomac River, 2007
}

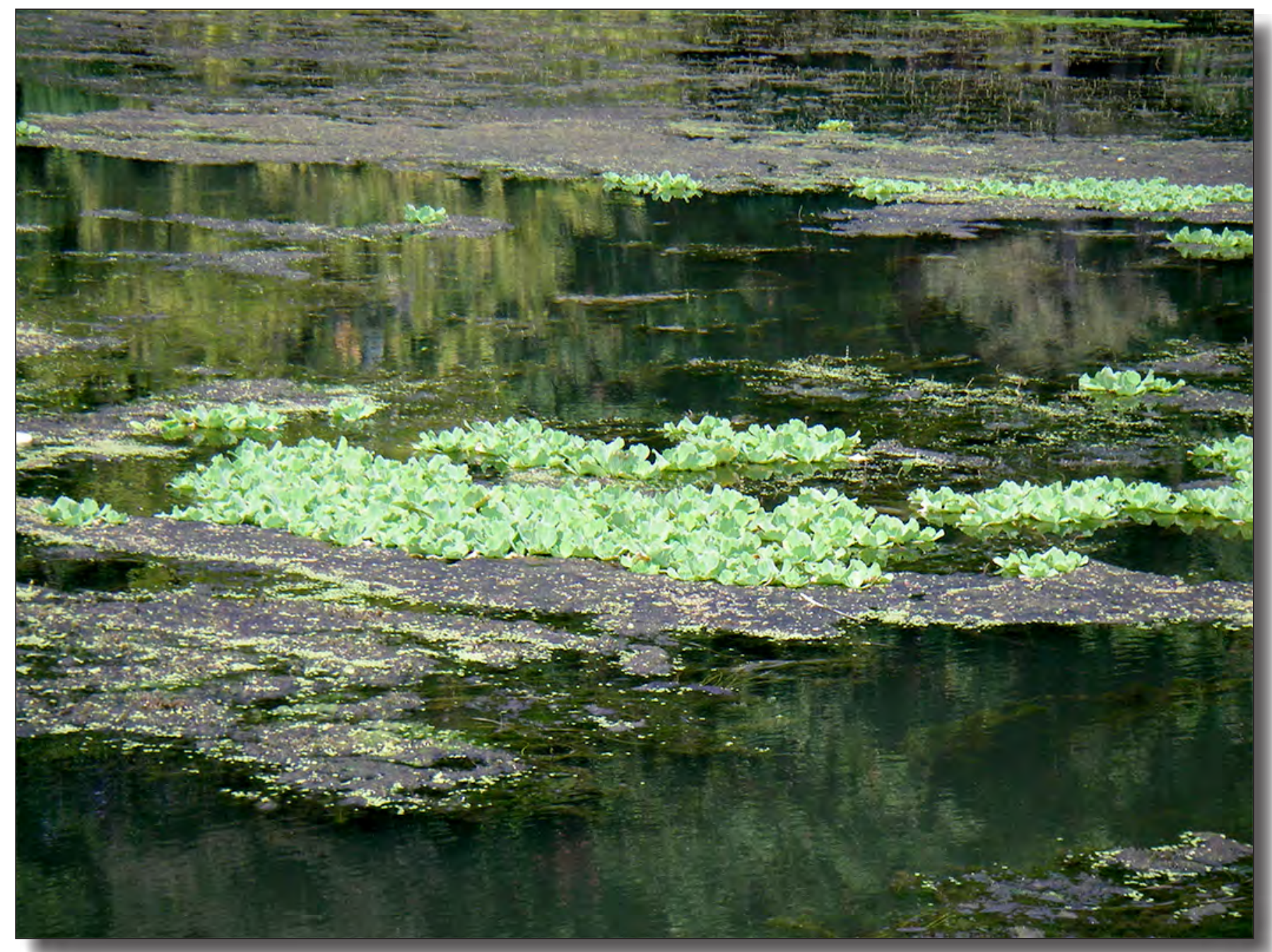

Open-File Report 2014-1259 
Cover: During autumn 2007, in the Mattawoman Creek and other locations in the Potomac River, single plants and clusters of water lettuce were discovered growing over the top of submersed aquatic vegetation beds. (Photograph by Nancy Rybicki.) 


\section{The Distribution of Submersed Aquatic Vegetation and Water Lettuce in the Fresh and Oligohaline Tidal Potomac River, 2007}

By Sarah Hunter Campbell, Nancy B. Rybicki, and Edward R. Schenk

Open-File Report 2014-1259 


\title{
U.S. Department of the Interior SALLY JEWELL, Secretary
}

\section{U.S. Geological Survey Suzette M. Kimball, Acting Director}

\author{
U.S. Geological Survey, Reston, Virginia: 2015
}

For more information on the USGS - the Federal source for science about the Earth, its natural and living resources, natural hazards, and the environment, visit http://www.usgs.gov or call 1-888-ASK-USGS.

For an overview of USGS information products, including maps, imagery, and publications, visit http://www.usgs.gov/pubprod

To order this and other USGS information products, visit http://store.usgs.gov

Any use of trade, firm, or product names is for descriptive purposes only and does not imply endorsement by the U.S. Government.

Although this information product, for the most part, is in the public domain, it also may contain copyrighted materials as noted in the text. Permission to reproduce copyrighted items must be secured from the copyright owner.

Suggested citation:

Campbell, S.H., Rybicki, N.B., and Schenk, E.R., 2015, The distribution of submersed aquatic vegetation and water lettuce in the fresh and oligohaline tidal Potomac River, 2007: U.S. Geological Survey Open-File Report 2014-1259, 33 p., http://dx.doi.org/10.3133/ofr20141259.

ISSN 2331-1258 (online) 


\section{Acknowledgments}

This work could not have been completed without the help of volunteers who, alongside U.S. Geological survey staff, worked long hours on the boat to gather data: Patti Marcoe, Barbara Bartow, and Paul Roche. We are also grateful to Curtis Dalpra, from the Interstate Commission on the Potomac River Basin, who identified water lettuce in the Potomac while volunteering his assistance with the shoreline survey on October 6, 2007. Support for this study is gratefully acknowledged from the U.S. Army Corps of Engineers, Baltimore, Maryland; the Metropolitan Washington Council of Government's Aquatic Plant Management Program; and the Fisheries Division of the District of Columbia Department of Health.

U.S. Geological Survey programs providing support for this study were the National Research Program and Chesapeake Bay Program. 


\section{Contents}

Abstract
Introduction
Methods
Results $\quad$ Upper Tidal Potomac River
$\quad$ Upper 0 ligohaline Potomac River Estuary
References Cited

\section{Figures}

1. Study area showing the three river segments of the Potomac River and the locations of the Aquatic Plant Management Program harvest sites in the tidal Potomac River.

2. Percent cover of hydrilla in submersed aquatic vegetation beds located in the tidal Potomac River from Washington, D.C., to Dogue Creek, Va., 2007

3. Percent cover of hydrilla in submersed aquatic vegetation beds located in the tidal Potomac River from Dogue Creek, Va., to Quantico Creek, Va., 2007

4. Percent cover of hydrilla in submersed aquatic vegetation beds located in the tidal Potomac River from Chopawamsic Creek, Va., to the end of the river segment, 2007

5. Location of each field bed in a continuous shoreline survey of Washington, D.C., 2007.

6. Location of each field bed in a continuous shoreline survey from Washington, D.C., to Broad Creek, Md., 2007

7. Location of each field bed in a continuous shoreline survey from Swan Creek, Md., to Gunston Cove, Va., 2007.

8. Location of each field bed in a continuous shoreline survey from Mason Neck, Va., to Quantico Creek, Va., 2007

9. Location of each field bed in a continuous shoreline survey near Quantico, Va., and Mallows Bay, Md., 2007

10. Location of each field bed in a continuous shoreline survey from Wades Bay, Md., to Potomac Creek, Va., 2007.

11. Location of each field bed in a continuous shoreline survey from Aquia Creek, Va., to the end of the river segment, 2007.

12. Distribution of water lettuce in the tidal Potomac River between Mason Neck and Aquia Creek, Va., 2007

13. Distribution and density of submersed aquatic vegetation and the locations of the aquatic plant management harvest sites in the tidal Potomac River from Washington, D.C., to Broad Creek, Md., 2007

14. Distribution and density of submersed aquatic vegetation and the locations of the aquatic plant management harvest sites in the tidal Potomac River from Chopawamsic Creek, Va., to the downstream extent of the study, 2007. 
15. Distribution and density of submersed aquatic vegetation and the locations of the aquatic plant management harvest sites in the tidal Potomac River from Broad Creek, Md., to Chopawamsic Creek, Va., 2007...............................................22

16. Percent of available habitat that was vegetated in each river segment from 1985 to 2007.

17. Area occupied by submersed aquatic vegetation for each river segment from 1985 to 2007.

\section{Table}

1. Percent canopy cover of each species and Shannon diversity index for field beds in the tidal Potomac River, 2007

\section{Conversion Factors}

\begin{tabular}{lcl}
\multicolumn{1}{c}{ SI to Inch/Pound } & & \\
\hline \multicolumn{1}{c}{ Multiply } & By & To obtain \\
\hline meter $(\mathrm{m})$ & Length & \\
kilometer $(\mathrm{km})$ & 3.281 & foot $(\mathrm{ft})$ \\
meter $(\mathrm{m})$ & 0.6214 & mile $(\mathrm{mi})$ \\
& 1.094 & yard $(\mathrm{yd})$ \\
\hline square kilometer $\left(\mathrm{km}^{2}\right)$ & Area & \\
square meter $\left(\mathrm{m}^{2}\right)$ & 247.1 & acre \\
square kilometer $\left(\mathrm{km}^{2}\right)$ & 10.76 & square foot $\left(\mathrm{ft}^{2}\right)$ \\
\hline
\end{tabular}




\title{
The Distribution of Submersed Aquatic Vegetation and Water Lettuce in the Fresh and Oligohaline Tidal Potomac River, 2007
}

\author{
By Sarah Hunter Campbell, ${ }^{1}$ Nancy B. Rybicki, ${ }^{2}$ and Edward R. Schenk ${ }^{2}$
}

\begin{abstract}
Surveys documenting the composition of species of submersed aquatic vegetation (SAV) have been conducted in the Potomac River for decades. These surveys can help managers assess the proportion of native and exotic plants in the river or can be used to determine relationships between native and exotic plants, environmental conditions, and wildlife. SAV coverage increased from 2005 to 2007 throughout the fresh and oligohaline study area. The 2007 survey documented here determined that eleven species of SAV were present. The abundance of the exotic species Hydrilla verticillata (hydrilla) was relatively low, and species diversity was relatively high compared to previous years. The survey also revealed a new population of the invasive, floating aquatic plant Pistia stratiotes (water lettuce). In 2007, water lettuce, the latest exotic aquatic plant to be found in the fresh to oligohaline portion of the Potomac River, was most abundant in Mattawoman Creek, Charles County, Maryland. However, it was not observed in the fresh to oligohaline portion of the Potomac River in the summer of 2008. An understanding of the distribution of SAV species and factors governing the abundance of native and invasive aquatic species is enhanced by long-term surveys.
\end{abstract}

\section{Introduction}

Submersed aquatic vegetation (SAV) is a critical component of the Potomac River ecosystem (fig. 1). Although SAV provides important habitat for fauna and stabilizes bottom sediment, very dense beds may restrict recreational and commercial navigation. Exotic species of SAV were managed by the Metropolitan Washington Council of Governments from 1986 to 2007 as part of the Potomac Aquatic Plant Management Program (PAPMP). Selected beds of primarily exotic SAV species that limit navigation were harvested mechanically. The program began in 1986 when approximately 40 acres of plants were harvested from 18 sites (fig.1; Metropolitan Washington Council of Governments, 1987).

Monitoring efforts are an effective means of quantifying the distribution and abundance of the four exotic species in the river ecosystem - Hydrilla verticillata (hydrilla), Najas minor (naiad), Potamogeton crispus (curly pondweed), and Myriophyllum spicatum (milfoil) — and nine other native SAV species. In 2007, the U.S. Geological Survey (USGS) monitoring efforts led to the discovery of a substantial population of Pistia stratiotes (water lettuce), an exotic subtropical species of floating aquatic vegetation (Langeland and Burks, 1998). This was the first documented siting of this species in the Potomac River.

Annual surveys of SAV beds provide a basis for identifying large-scale changes and trends throughout the ecosystem and allow managers to evaluate the effectiveness of resource management policies directed toward improving water quality (Rybicki and Landwehr, 2007) and managing invasive plants (Hershner and Havens, 2008). The USGS has monitored the distribution and composition of SAV beds in the fresh and oligohaline (salinity 0.5 to 5) tidal Potomac River from 1978 to 2007 by using transect sampling (1978 to 1981, 1985 to 1987, 2002, and 2006) and shoreline surveys (1983 to 2005 and 2007; Rybicki and Landwehr, 2007, Ruhl and Rybicki, 2010). No shoreline survey was conducted in 2006; instead, 15 transects were sampled in the tidal fresh and oligohaline Potomac River between Piscataway and Pomonkey Creeks on both Maryland and Virginia shores on May 8 and October 18. Since 1998, the government of the District of Columbia has conducted surveys and provided the data to the USGS for the Washington, D.C. portion of the Potomac and Anacostia Rivers (Rottman, 1999; Ryan, 2005, 2006, 2007, 2008).

A list of species of SAV observed in beds in the tidal Potomac River is incorporated into the Virginia Institute of Marine Science (VIMS) annual report on SAV distribution in the Chesapeake Bay. The VIMS report and methods are available at $h t t p: / /$ www.vims.edu/bio/sav (Orth and others, 2008). Additional publications concerning SAV distribution in the Potomac River can be found at http://water.usgs.gov/nrp/proj.bib/sav/wethome.htm.

\footnotetext{
${ }^{1}$ Aarcher, Inc.

${ }^{2}$ U.S. Geological Survey.
} 


\section{Methods}

During the 2007 survey, the study area in the Potomac River was divided into three reaches: (1) upper tidal river (UTR), (2) lower tidal river (LTR), and (3) upper oligohaline estuary (UOE) (fig. 1). Observations of species composition in SAV beds were done by boat at approximately low tide ( \pm 2 hours) to optimize SAV visibility from the water surface. Surveys were conducted from August to October 2007. Researchers identified submersed plants to species level, recorded the species composition of each bed, and estimated the percent cover for each species within the bed. As in previous years, the USGS monitored areas downriver from the Woodrow Wilson Bridge (Interstate 95), whereas colleagues at the District of Columbia District Department of the Environment (DDOE) examined Washington, D.C. waters in the tidal Anacostia and Potomac Rivers (Rottman 1999; Ryan 2008).

The monitoring effort in 2007 consisted of a continuous survey of all shoals and SAV beds within the study area (fig. 1). SAV field beds are the isolated or contiguous SAV beds of different species composition sampled by boat. USGS personnel outlined SAV beds on 1:24,000-scale USGS quadrangle maps, indicating the location of all observations including unvegetated shoals (see Ruhl and others, 1999). DDOE personnel used a global positioning system (GPS) to delineate the perimeter or length of beds and to record locations of each field bed. The SAV beds documented by the USGS and DDOE were then entered into a geographic information system (GIS) to create maps of distribution and abundance. The observation date, percent of each species, Shannon diversity index, and bed density for each field bed are listed in table 1 . The Shannon diversity index for each field bed is calculated as:

$$
\text { Diversity }=-1 \times \sum_{\mathrm{v}=1}^{\mathrm{M}}((\mathrm{Pv} / 100) \times \ln (\mathrm{Pv} / 100))
$$

where

$$
\begin{array}{cl}
\mathrm{M} & \text { represents richness (the total number of species observed), } \\
\mathrm{Pv} & \text { represents the proportional coverage (from } 0 \text { to } 100 \text { percent) of each species, and } \\
\mathrm{V} & \text { represents each species from } 1 \text { to M. }
\end{array}
$$

Diversity in each bed can range from 0.00 (if one species is present) to 2.49 (if all 12 species commonly found in the Potomac are present in equal percentages). The percent cover data for each species shown in table 1 corresponds to field bed locations shown in figures 2 to 12. Observations of the percent cover of colonies of water lettuce on top of SAV beds or the observation of a single cluster of plants floating in the channel were made from October 6 to October 18.

SAV beds shown in figures 13, 14, and 15 were delineated by VIMS (http://www.vims.edu/bio/sav/) on the basis of aerial photographs acquired from August to October, then digitized and classified for ground cover density (from estimates of percent cover). The area and density of each photo-interpreted (PI) bed was determined by VIMS. Density was determined using the Crown Density Scale adapted from Paine (1981). Bed densities range from 1 to 4, with a density of 1 corresponding to less than 10 percent vegetation coverage, a density of 2 representing from 10 to 40 percent coverage, a density of 3 representing from 41 to 70 percent coverage, and a density of 4 corresponding to 71 to 100 percent coverage. The VIMS delineation process resulted in bed area outlines to which corresponding field data on species composition were added. Some SAV beds were visible with aerial photography but were not observed in the field if the area was not navigable due to water depth or obstacles. The VIMS SAV coverage data did not include beds below their detection limit. Therefore, beds shown in figures 2 to 4 do not correspond exactly with VIMS beds.

The percent cover for each species in the three river segments (UTR, LTR, UOE) is summarized in the results section. The area of each species within a VIMS PI bed is computed on the basis of a weighted-average formula. Using GIS software, each of the field beds was aligned with the PI beds to determine the area of each field bed and subsequently to calculate the coverage by species in each PI bed where species data were available. If more than one field observation was made in a PI bed, the PI bed area was subdivided according to the relative size of each field bed and averaged species data proportionally (weighted average) to determine the percentage of each species in a PI bed and in the cumulative area of the study in each river reach (Rybicki and Landwehr, 2007).

Aquatic plant managers also need to know if species composition fluctuated from dominance of one species to another or if SAV coverage persisted at a location between years. Therefore, comparisons of spatial coverage of SAV and dominant species (coverage $\geq 40$ percent) between 2007 (this study) and 2005 (Rybicki and others, 2008) or previous years (Ruhl and others, 1999; Ruhl and Rybicki, 2010; http://www.vims.edu/bio/sav/) are described for each river segment. The description of temporal spatial patterns in exotic species coverage enhances management efforts to understand interannual variation in SAV and predict the need for harvesting exotic species the following year. 


\section{Results}

The shoreline survey included 274 observations of field beds of various sizes $\left(72 \mathrm{~m}^{2}\right.$ to $\left.313 \mathrm{~km}^{2}\right)$ and densities (table 1). Many of the PAPMP harvest sites in the UTR, LTR, and UOE had 70 to 100 percent cover (figs. 13 to 15). Of the 11 species observed in the Potomac River in 2007, four were exotic (hydrilla, milfoil, naiad, and curly pondweed). Hydrilla did not dominate (coverage $\geq 40$ percent) in any river segment in 2007, whereas from 1985 to 2005 , hydrilla was frequently the dominant species in most river segments (Rybicki and Landwehr, 2007; Ruhl and Rybicki, 2010; Rybicki and others, 2008). Hydrilla and Ceratophyllum demersum (coontail) were the most abundant species in the UTR; milfoil was the most abundant species in the LTR and the UOE. Naiad coverage was similar to previous years, comprising 5 to 15 percent of SAV coverage in the river segments. Vallisneria americana (wild celery) SAV coverage was low in 2007, comprising 1 to 10 percent of SAV coverage in the river segments. As in 2005, Elodea spp. (waterweed) was not present in 2007, but Stuckenia pectinata (sago pondweed) and curly pondweed were observed in trace amounts. Some species were relatively rare, namely the macroalga Chara vulgaris (muskgrass), Potamogeton pusilus (slender pondweed), and Potamogeton perfoliatus (redhead grass). Najas guadalupensis (southern naiad) and Heteranthera dubia (water stargrass) were rare in 2005, but increased substantially in 2007.

Water lettuce was observed in approximately 161 hectares in the LTR and UOE in 2007. The floating aquatic vegetation was found in the river in various locations between Mason Neck and Aquia Creek (fig. 12). These discoveries led to an organized effort to monitor for water lettuce in 2008. The Freshwater Submerged Aquatic Vegetation Partnership, a group of Federal, State and university staff focused on aquatic plants, convened a group to determine if the water lettuce, a subtropical plant, could overwinter and survive in the Potomac River the following year. The Partnership members made observations from boats throughout the fresh to oligohaline portion of the Potomac River in the summer of 2008. They found no water lettuce in the study area in 2008. In addition, signage was placed at boat ramps in Maryland to educate the public not to release exotic aquatic species into the waterways and to report observations of water lettuce to Maryland Department of Natural Resources.

The percent of available habitat (area less than $2 \mathrm{~m}$ deep) that was vegetated varied over time in the UTR, LTR, and UOE but was at a maximum in 2007 in all river segments (fig. 16). However, no river segment has had vegetation in more than 60 percent of the available habitat from 1985 to 2007. SAV coverage increased from 2005 to 2007 throughout the fresh and oligohaline study area (fig. 17).

\section{Upper Tidal Potomac River}

In the upper tidal river (UTR), the following eight SAV species were found in 2007, in order from most to least abundant: hydrilla (28 percent), coontail (28 percent), milfoil (16.5 percent), naiad (15 percent), water stargrass ( 7.5 percent), and southern naiad, wild celery, or curly pondweed (less than 5 percent). Compared to 2005, coontail, naiad, southern naiad, and water stargrass coverage increased in 2007, while hydrilla and wild celery coverage decreased and milfoil coverage remained the same. Muskgrass was not observed in 2007, although it has been found in this segment of the river in trace amounts for the past few years. Curly pondweed was observed in this segment of the study area for the first time in several years. The number of species observed in the UTR decreased from nine in 2005 to eight in 2007.

No SAV was observed in the Washington, D.C. portion of the tidal Anacostia River (fig. 5), yet a few beds were present there in the past. A perennial bed that has persisted for many years in the Washington Channel, at the confluence of the Anacostia River and Potomac River, was not observed in 2007.

In Washington, D.C., SAV coverage in 2007 (figs. 2, 5, 13, and 16) increased substantially from 2005. Coverage was higher in 2007 than it had been for several years. SAV coverage in Washington, D.C. waters declined dramatically after 2003 when precipitation and river flow (USGS gage station 01646500, http://waterdata.usgs.gov/nwis/sw) were well above average. The high sediment load and high flows may have buried SAV or scoured it away, or the cloudy conditions and muddy waters reduced available light reaching the bottom and diminished SAV productivity. SAV was abundant from the Chain Bridge to Roosevelt Island in 2007 (figs. 2, 5, and 13; table 1) for the first time since 2002 (http://www.vims.edu/bio/sav). The beds north of Roosevelt Island to the Chain Bridge were dominated by water stargrass, although hydrilla and naiad were also found in many of the beds in 2007 (fig. 5; table 1). These beds were relatively small. The beds around Roosevelt Island were dominated by hydrilla, although water stargrass was present in many beds. Small populations of wild celery and naiad were also observed.

SAV coverage along the Washington, D.C. shoreline of the Potomac River south of Roosevelt Island in 2007 (figs. 2, 5, and 13; table 1) increased substantially from 2005. Wild celery dominated most of these beds, although water stargrass and hydrilla were also observed. SAV beds along the Virginia shoreline of the Potomac River south of Roosevelt Island also expanded since 2005. In contrast, a large bed that was present near a creek at Reagan National Airport in 2005 was not observed in 2007. These beds along the Virginia shoreline alternated in dominance between hydrilla and water stargrass; however, naiad and coontail were also observed there in 2007. 
The Distribution of Submersed Aquatic Vegetation and Water Lettuce in the Fresh and Oligohaline Tidal Potomac

In 2007, vegetation along the Virginia side of the Potomac River from National Airport to the Woodrow Wilson Bridge was intermittent and diverse; the beds contained water stargrass, coontail, hydrilla, naiad, and milfoil (figs. 2, 6, and 13; table 1), where, in 2005, the beds consisted mostly of hydrilla and some naiad. Large, dense beds were present in the middle of the Potomac River, just upstream from the Woodrow Wilson Bridge (figs. 6 and 13). These beds were also diverse, containing hydrilla, coontail, milfoil, naiad, water stargrass, and southern naiad. The SAV bed last observed in 2002 in the middle of the Potomac River just south of the Woodrow Wilson Bridge returned in 2007 and was dominated by hydrilla (figs. 2, 3, and 13).

SAV beds along the Maryland shore in the UTR in 2007 were dominated by hydrilla or coontail with milfoil, naiad, and water stargrass mixed in (figs. 2 and 6; table 1). Beds just north of Broad Creek were dominated by coontail, although hydrilla was abundant and water stargrass, naiad, and wild celery were also observed. Broad Creek was dominated by coontail, as were the beds located along the shore south of Broad Creek to Swan Creek. SAV beds in Swan Creek were dominated by coontail in 2007 (fig. 7), but were dominated by hydrilla in 2005. Hydrilla dominated the SAV beds along the Maryland shore south of Swan Creek to Piscataway Creek in 2007 (figs. 2 and 7). On the upstream shore of Piscataway Creek, beds were dominated by hydrilla while beds in the middle of the creek had less than 40 percent hydrilla, and also contained coontail, water stargrass, and naiad. The beds on the downstream shore of Piscataway Creek were often dominated by coontail, as were those located along the Maryland shore throughout the lower extent of the UTR. However, beds were occasionally dominated by hydrilla and contained a mixture of other SAV in 2007.

SAV coverage was continuous along the Virginia shore between Hunting Creek and Little Hunting Creek in 2007 (fig. 2); however, SAV beds were not observed in the upper half of that Virginia shore in 2005. The new beds were dominated by hydrilla, although coontail and naiad were abundant and wild celery, water stargrass, southern naiad, and milfoil were also observed in 2007 (figs. 2, 6, and 7; table 1). The number of species observed in the beds along the Virginia shore increased substantially from 2005 to 2007. In 2005, hydrilla and milfoil altered in dominance along the Virginia shore south to Little Hunting Creek and coontail was abundant. In 2007, hydrilla dominated a couple of beds, but coontail, naiad, southern naiad, and milfoil were abundant and water stargrass and wild celery were also observed. Hydrilla dominated the beds at the mouth of Little Hunting Creek, but those were also well mixed with other common species of SAV. Fairly large beds were observed in 2007 in the channel of the Potomac River in front of Little Hunting Creek that extended south of the creek to the midway point between Little Hunting Creek and Dogue Creek. These beds in the channel were dominated by coontail, although near the southern end of the channel beds there was a bed dominated by milfoil. Hydrilla, naiad, and southern naiad were also observed in these beds. The SAV beds along the Virginia shore south of Little Hunting Creek to the lower extent of the UTR were dominated by milfoil, well mixed with coontail, hydrilla, and to a lesser extent, naiad and southern naiad. In 2005, the lower extent of the UTR on the Virginia shore was dominated by wild celery, but in 2007 very little was observed. Milfoil, coontail, and hydrilla altered in dominance in Dogue Creek, but southern naiad and naiad were also observed in 2007.

The shore just upstream from Little Hunting Creek supported the only traces of muskgrass in the entire study area in 2005, while in 2007, muskgrass was not observed at all in the UTR (fig. 7; table 1). Trace amounts of sago pondweed were also observed in the UTR in 2005, but sago pondweed was not observed in 2007. A small population of curly pondweed was observed in 2007; it had not been observed in Dogue Creek since 1999.

\section{Lower Tidal Potomac River}

In the lower tidal river (LTR) in 2007, 11 SAV species were found. The SAV coverage was, from most to least abundant, milfoil ( 32 percent), hydrilla ( 26 percent), coontail ( 20 percent), naiad ( 9 percent), wild celery ( 8 percent), and southern naiad, water stargrass, muskgrass, curly pondweed, slender pondweed, and redhead grass (less than 5 percent). SAV coverage increased from 2005 to 2007 for most species, with milfoil exhibiting the greatest increase. Milfoil was the most abundant species of the LTR in 2007, whereas hydrilla was the dominant species in 2005. Hydrilla and wild celery coverage dropped by almost half, while coontail coverage remained the same from 2005 to 2007. Four species were new to this segment of the study area since 2005, and all were in trace amounts in 2007: muskgrass, curly pondweed, slender pondweed, and redhead grass. The number of species in this segment of the study area increased from 7 to 11 species from 2005 to 2007.

Hydrilla was the dominant species in the beds on the upstream shore of Gunston Cove, similar to 2005. Milfoil dominated the SAV beds along the downstream shore of Gunston Cove and dominated a small bed in the middle of the mouth of the cove in 2007 (figs. 3 and 7; table 1). SAV beds in the back of Gunston Cove alternated in dominance between milfoil, southern naiad, coontail, and hydrilla, where hydrilla dominated most of these beds in 2005. A small population of water stargrass was also observed in these beds in 2007, where it was not present in 2005. In the narrow fringing downstream beds of Gunston Cove, naiad, wild celery, and hydrilla were the most abundant species in 2007. Hydrilla was the most abundant species and dominated some beds in locations across from Gunston Cove and south of Pomonkey Creek, on the Maryland side of the Potomac River. However, water stargrass, coontail, and milfoil were also abundant species with a smaller presence of naiad, southern naiad, and wild celery in 2007. 
Hydrilla was the dominant species in the beds on the upstream shore of Gunston Cove, similar to 2005. Milfoil dominated the SAV beds along the downstream shore of Gunston Cove and dominated a small bed in the middle of the mouth of the cove in 2007 (figs. 3 and 7; table 1). SAV beds in the back of Gunston Cove alternated in dominance between milfoil, southern naiad, coontail, and hydrilla, where hydrilla dominated most of these beds in 2005. A small population of water stargrass was also observed in these beds in 2007, where it was not present in 2005. In the narrow fringing downstream beds of Gunston Cove, naiad, wild celery, and hydrilla were the most abundant species in 2007. Hydrilla was the most abundant species and dominated some beds in locations across from Gunston Cove and south of Pomonkey Creek, on the Maryland side of the Potomac River. However, water stargrass, coontail, and milfoil were also abundant species with a smaller presence of naiad, southern naiad, and wild celery in 2007.

Wild celery was the dominant species around Mason Neck (Virginia) in 2007, as also was observed in 2005. Milfoil was the dominant species at the mouth of Pomonkey Creek in 2007 (figs. 7 and 8), where hydrilla dominated in 2005. However, the beds at the mouth and in Pomonkey Creek were well mixed with coontail, water stargrass, hydrilla, and small populations of southern naiad, naiad, and wild celery in 2007 (figs. 3 and 8; table 1). SAV was sparse at Indian Head between Pomonkey Creek and downstream to Mattawoman Creek and consisted mainly of beds that altered in dominance between water stargrass, milfoil, hydrilla, and naiad. Small populations of coontail and southern naiad were also observed along this portion of the Maryland shore in 2007 (fig. 8; table 1).

SAV coverage in the Mattawoman Creek increased substantially from 2005. Coontail, milfoil, and hydrilla were abundant in the mouth of the Mattawoman in 2007 (figs. 3, 8, and 14; table 1). Wild celery was one of the dominant species in 2005, but in 2007 only a few small populations were observed at the mouth and in the middle of the creek. There was a substantial increase in milfoil coverage through much of the Mattawoman, where it dominated several beds throughout the creek. Hydrilla was dominant in the upstream portions of the Mattawoman Creek, but occasionally there were beds dominated by coontail. Naiad decreased while southern naid increased from 2005 to 2007 (fig. 8; table 1). Southern naiad was only found in trace amounts in 2005.

SAV coverage decreased in Chicamuxen Creek from 2005 to 2007. Coontail and milfoil were again the most abundant species and smaller populations of hydrilla, wild celery, naiad, and water stargrass were observed in 2007 (figs. 3, 8, 9, and 14; table 1). Chicamuxen Creek is traditionally one of the more diverse beds in the study area, although in 2007, the number of species decreased as a result of the lack of southern naiad.

SAV coverage in Belmont Bay increased substantially from 2005 to 2007. In 2005, hydrilla, southern naiad, and wild celery were found in the three beds observed. In addition to those species observed in 2005, in 2007 milfoil and trace amounts of slender pondweed and redhead grass were found (figs. 3, 8, and 14; table 1). New beds were observed along the shore on the upstream side of the mouth of Belmont Bay, where milfoil, coontail, hydrilla, and wild celery were abundant and supported the only population of muskgrass found in the entire study area. Hydrilla and southern naiad alternately dominated beds along the upstream shore of Belmont Bay; these beds also supported the only populations of slender pondweed and redhead grass in the study area. In the remainder of Belmont Bay and at the mouth of the Occoquan River, hydrilla, milfoil, and wild celery altered in dominance.

Neabsco Creek was dominated by hydrilla in 2007 (fig. 3), as it was in 2005. SAV coverage and diversity in Powells Creek and along the Virginia shore south to Quantico Creek increased considerably in 2007 (figs. 9 and 14; table 1). The SAV beds in Powells Creek were well mixed with coontail, hydrilla, southern naiad, wild celery, and milfoil in 2007, where hydrilla was dominant in 2005. Beds just south of the mouth of Powells Creek along the shore were dominated by wild celery, but along the shore closer to Quantico Creek and into the creek, the beds were very diverse, with milfoil dominating one bed on the upstream shore of the mouth of Quantico Creek. In 2005, hydrilla and coontail altered in dominance in Quantico Creek, but in 2007, milfoil, coontail, wild celery, hydrilla, and southern naiad were very abundant throughout the creek (figs. 3, 8, and 9; table 1).

The floating aquatic vegetation, water lettuce, was first discovered October 6 in the Mattawoman Creek. Afterwards it was also found in various beds in Chicamuxen Creek, Powells Creek, and Quantico Creek in this segment of the study area in 2007 (fig. 12). Water lettuce did not exceed 10 percent coverage of any bed shown in figure 12. It was always located with SAV except where it was floating free in the channel of the Potomac River near Mason Neck.

\section{Upper Oligohaline Potomac River Estuary}

Eight SAV species were present in 2007 in the upper oligohaline estuary (UOE) with the following composition: milfoil (40 percent), hydrilla (17 percent), stargrass (13 percent), coontail (12 percent), wild celery (9.5 percent), naiad (5 percent), and southern naiad and curly pondweed (less than 5 percent each). From 2005 to 2007, the coverage of milfoil increased substantially while hydrilla coverage, which was the dominant species in 2005 , decreased. Coontail coverage also decreased, but water stargrass, wild celery, naiad, and southern naiad coverage increased compared to previous years. Curly pondweed was observed 
The Distribution of Submersed Aquatic Vegetation and Water Lettuce in the Fresh and Oligohaline Tidal Potomac

for the first time in the UOE in 2007. In 2005, hydrilla was the dominant species in many locations along the Virginia side of the Potomac River and milfoil and wild celery were the dominant species along the Maryland side, but in 2007 the beds on both sides of the river were diverse. Rarely was any species $\geq 40$ percent of the total cover. The number of species observed in the UOE increased from eight in 2005 to nine in 2007.

Milfoil and wild celery codominated the only bed in the upper extent of the UOE on the Maryland side of the Potomac River north of Mallows Bay in 2007 (figs. 8 and 15; table 1), where milfoil and hydrilla were abundant in 2005. SAV in Mallows Bay consisted of three beds, one dominated by hydrilla, one by milfoil, and one by coontail in 2007 (figs. 4 and 8). Water stargrass, naiad, and southern naiad were also observed in 2007, whereas in 2005, only hydrilla, naiad, and coontail were observed. SAV coverage decreased in the bay north of Wades Bay and in Wades Bay from 2005 to 2007. One long bed extended through these two bays and was dominated by milfoil, although some wild celery, coontail, and water stargrass were also observed in 2007. Wild celery dominated Wades Bay in 2005 but milfoil was dominant in 2007 (fig. 10; table 1).

Water stargrass was the most abundant species in the cove south of Quantico, Va., and north of the Chopawamsic Creek in 2007 (fig. 9; table 1). Water stargrass, milfoil, and coontail were abundant in the region south of Quantico and along the shoreline south of Chopawamsic Creek. Water stargrass was observed in trace amounts in this area in 2005, but in 2007 it was abundant or dominant in many of the beds on the Virginia shore from Chopawamsic Creek to Aquia Creek (figs. 9 and 10; table 1).

In 2007, milfoil dominated many of the beds in Aquia Creek, although beds around the mouth of the creek were dominated by water stargrass (figs. 4 and 10; table 1). Hydrilla, coontail, wild celery, naiad, and southern naiad were also found in the creek in 2007. In 2005, many Aquia Creek beds were dominated by coontail and the upstream beds and the south shore of Aquia Creek were dominated by hydrilla. The southern shoreline at the mouth of Aquia Creek was dominated by milfoil in 2007. This was also true of the cove just below Aquia Creek, although one bed contained the only population of sago pondweed in the UOE. The beds located on the northern mouth of Aquia Creek and the upstream shore of Potomac Creek were codominated by southern naiad and hydrilla or were dominated by milfoil, with populations of coontail and water stargrass also observed in 2007 (figs. 4, 10, and 11; table 1). Within Potomac Creek, hydrilla dominated the SAV beds although wild celery, coontail, southern naiad, and water stargrass were also observed. One bed on the downstream shore of Potomac Creek was dominated by wild celery in 2007. SAV was not found beyond Potomac Creek in the lower extent of the UOE.

Water lettuce was observed in the cove below Quantico Creek, Wades Bay, and Aquia Creek in this segment of the study area (fig. 12). Similar to the LTR, water lettuce coverage never exceeded 10 percent of a SAV bed and was generally located with SAV in the UOE.

\section{References Cited}

Hershner, C., and Havens, K.J., 2008, Managing invasive aquatic plants in a changing system-Strategic consideration of ecosystem services: Conservation Biology, v. 22, no. 3, p. 544-550.

Langeland, K.A., Burks, K.C., eds., 1998, Identification and biology of non-native plants in Florida's natural areas: Gainesville, Fla., University of Florida, 165 p., http://www.fleppc.org/ID_book.htm.

Metropolitan Washington Council of Governments, 1987, Potomac: SAV news, no. 2, Summer 1987.

Orth, R.J., Wilcox, D.J., Whiting, J.R., Nagey, L.S., Owens, A.L., and Kenne, A.K., 2008, 2007 Distribution of submerged aquatic vegetation in the Chesapeake Bay and coastal bays: VIMS Special Scientific Report Number 151. Final report to U.S. EPA, Chesapeake Bay Program, Annapolis, Md., Grant No. CB973219-01-0, http://web.vims.edu/bio/sav/sav07/index.html.

Paine, D.P., 1981, Aerial photography and image interpretation for resource management: New York, John Wiley and Sons, $571 \mathrm{p}$.

Rottman, A., 1999, Aquatic vegetation monitoring 1998; Submitted to U.S. Fish and Wildlife Service for the Fisheries and Wildlife Division of the Government of the District of Columbia: Report F-2-8-13.

Ruhl, H.A., Rybicki, N.B., Reel, J.T., and Carter, V., 1999, Distribution and abundance of submersed aquatic vegetation in the Tidal Potomac River and Upper Potomac Estuary, Maryland, Virginia, and the District of Columbia, 1993-1998: U.S. Geological Survey Open-File Report 99-233, http://pubs.er.usgs.gov/publication/ofr99233.

Ruhl, H.A., and Rybicki, N.B., 2010, Long-term reductions in anthropogenic nutrients link to improvements in Chesapeake Bay habitat: Proceedings of the National Academy of Science, v. 107, no. 38, http://www.pnas.org/content/107/38/16566.full.pdf. 
Ryan, D., 2005, 2004 Submerged aquatic vegetation survey of the Potomac and Anacostia Rivers within the District of Columbia; Submitted to U.S. Fish and Wildlife Service for the Fisheries and Wildlife Division of the Government of the District of Columbia: Report F-2-R-19.

Ryan, D., 2006, 2005 Submerged aquatic vegetation survey of the Potomac and Anacostia Rivers within the District of Columbia; Submitted to U.S. Fish and Wildlife Service for the Fisheries and Wildlife Division of the Government of the District of Columbia: Report F-2-R-20.

Ryan, D., 2007, 2006 Submerged aquatic vegetation survey of the Potomac and Anacostia Rivers within the District of Columbia; Submitted to U.S. Fish and Wildlife Service for the Fisheries and Wildlife Division of the Government of the District of Columbia: Report F-2-R-21.

Ryan, D., 2008, 2007 Submerged aquatic vegetation survey of the Potomac and Anacostia Rivers within the District of Columbia; Submitted to U.S. Fish and Wildlife Service for the Fisheries and Wildlife Division of the Government of the District of Columbia: Report F-2-R-22.

Rybicki, N.B., and Landwehr, J.M., 2007, Long-term changes in abundance and diversity of macrophyte and waterfowl populations in an estuary with exotic macrophytes and improving water quality: Limnology and Oceanography, v. 52, no. 3, p. $1195-1207$.

Rybicki, N.B., Yoon, S.N., Schenk, E.R., and Baldizar, J.B., 2007, The distribution of submersed aquatic vegetation in the fresh and oligohaline tidal Potomac River, 2004: U.S. Geological Survey Open-File Report 2007-1198, 27 p., http://pubs.usgs.gov/ of $/ 2007 / 1198 /$.

Rybicki, N.B., Justiniano-Vélez, E., Schenk, E.R., and Hunter, S.E., 2008, The Distribution of submersed aquatic vegetation in the fresh and oligohaline tidal Potomac River, 2005: U.S. Geological Survey Open-File Report 2008-1218, 35 p., http://pubs. usgs.gov/of/2008/12. 


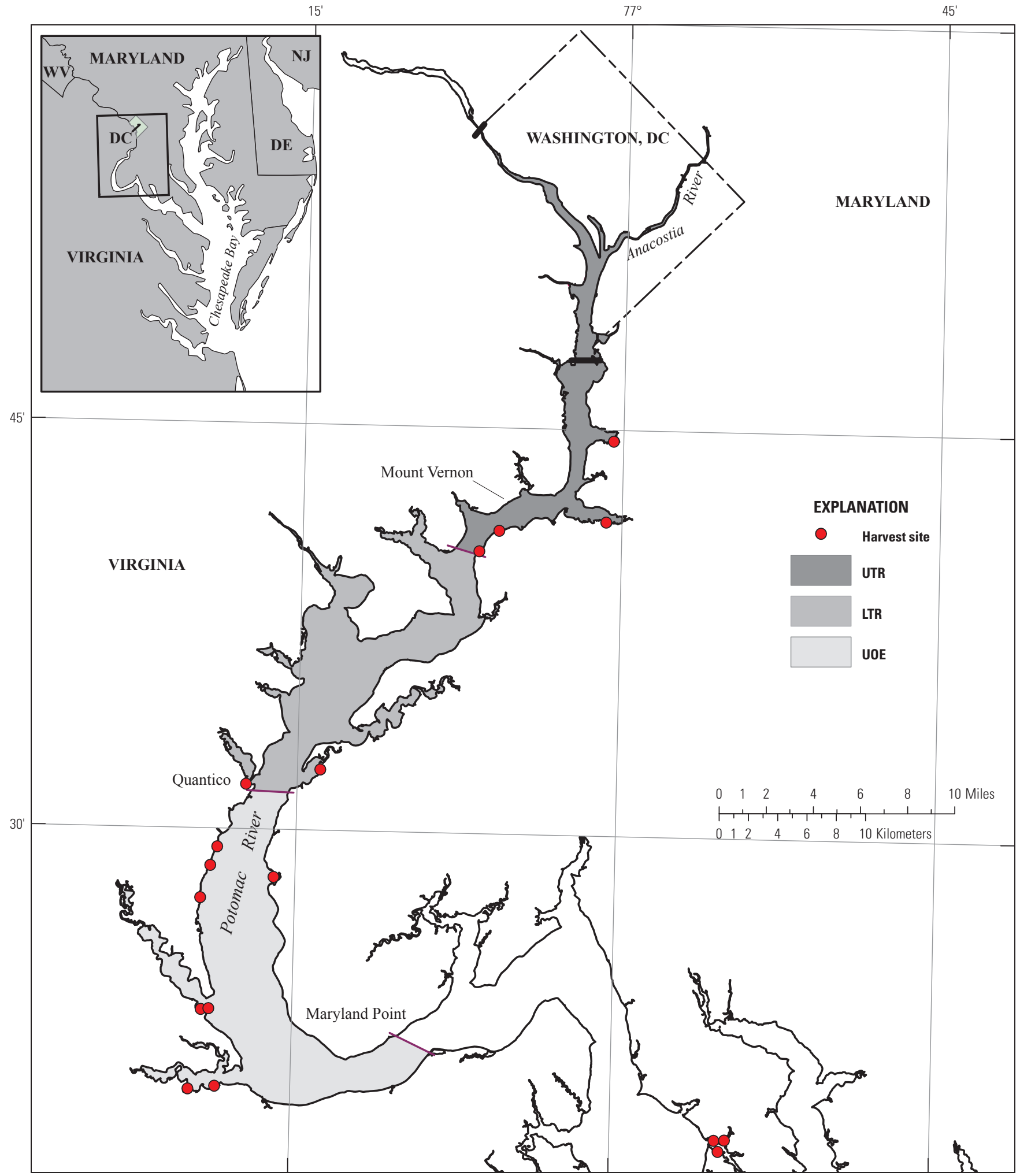

Figure 1. Study area showing the three river segments (UTR, upper tidal river, LTR, lower tidal river, and UOE, upper oligohaline estuary) of the Potomac River and the locations of the Aquatic Plant Management Program harvest sites in the tidal Potomac River. 


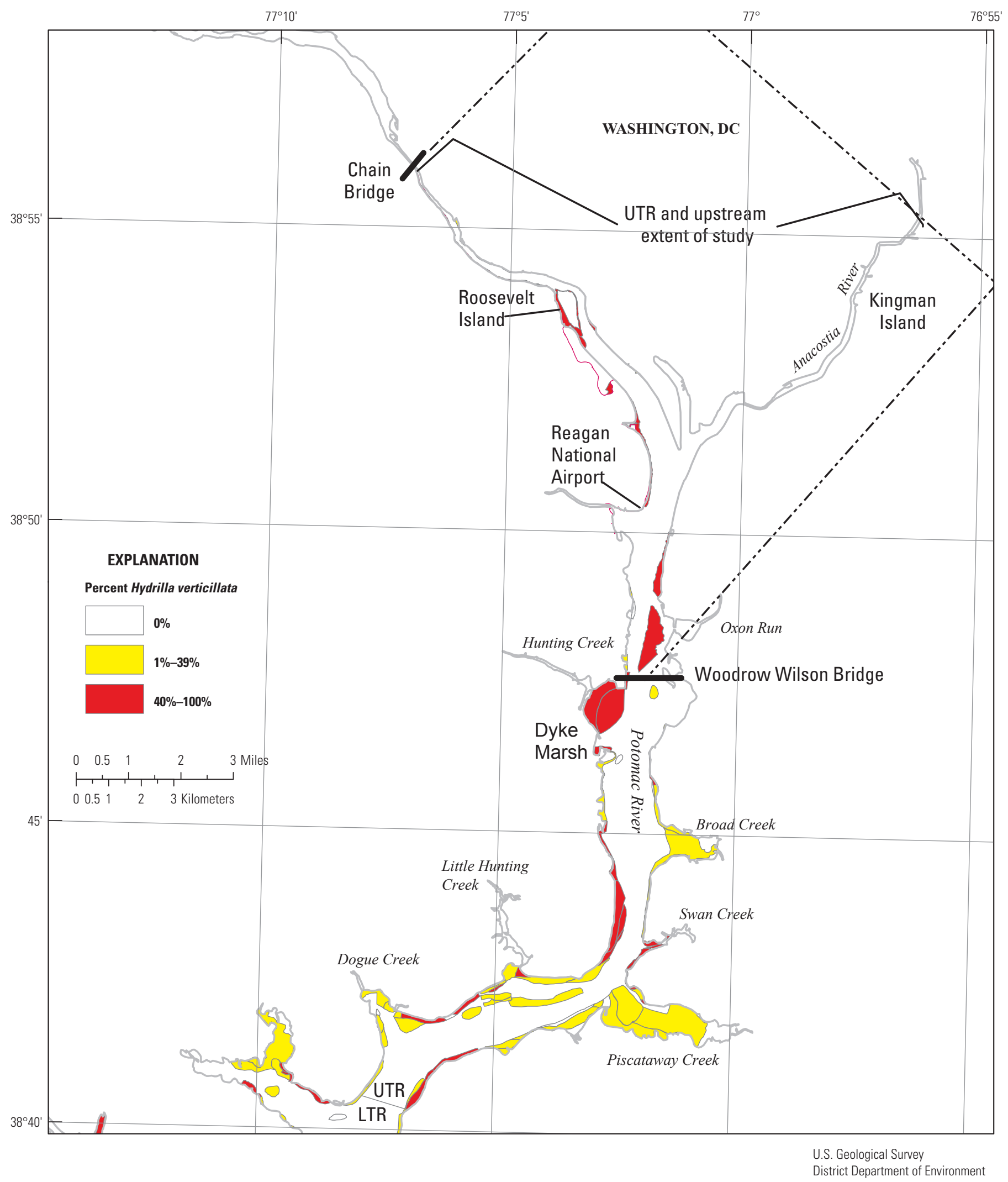

Figure 2. Percent (\%) cover of hydrilla in submersed aquatic vegetation beds located in the tidal Potomac River from Washington, D.C., to Dogue Creek, Va., 2007. UTR is the upper and LTR is the lower tidal river study segment. 


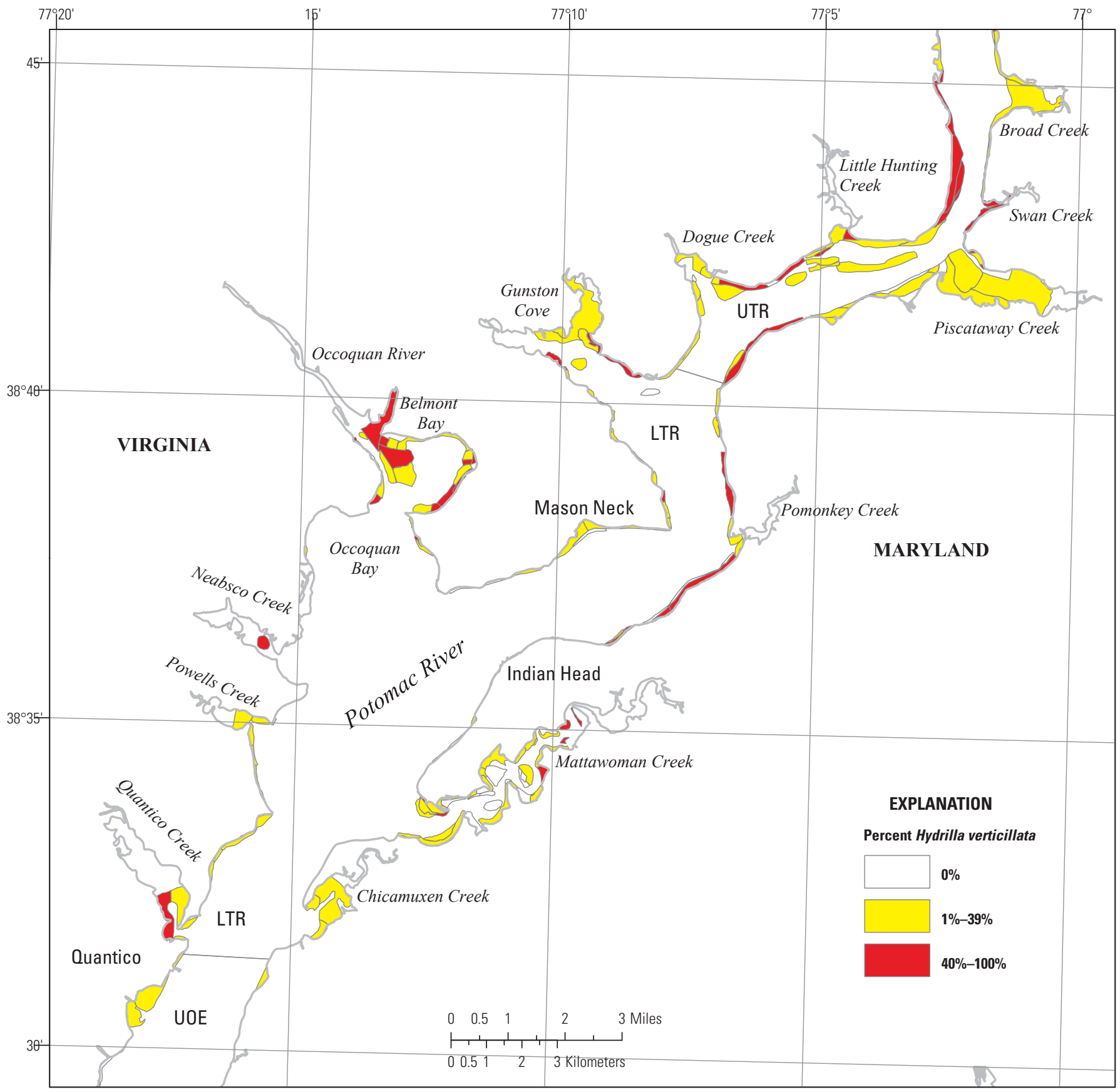

U.S. Geological Survey

Figure 3. Percent (\%) cover of hydrilla in submersed aquatic vegetation beds located in the tidal Potomac River from Dogue Creek, Va., to Quantico Creek, Va., 2007. UTR is the upper and LTR is the lower tidal river study segment. 

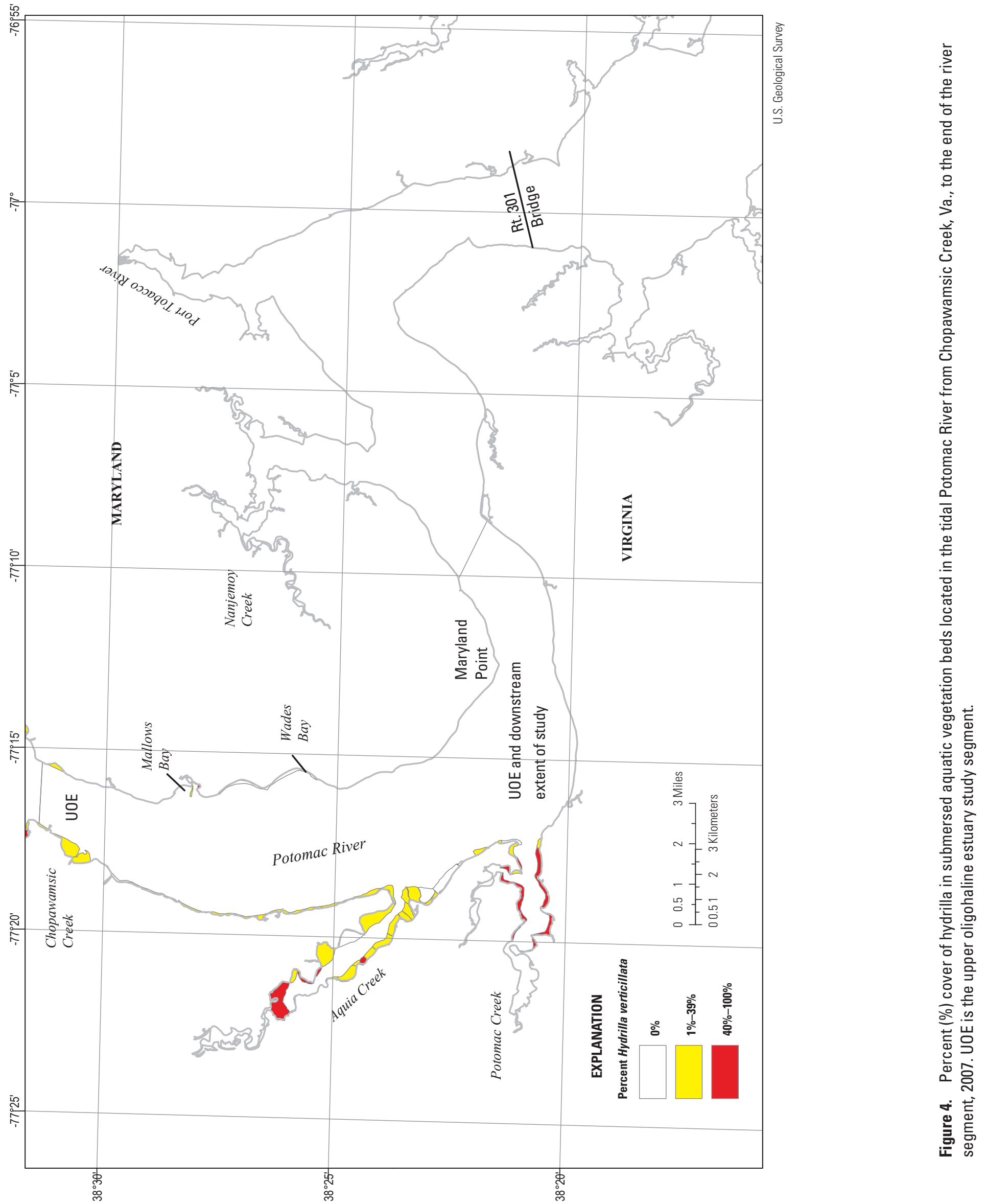


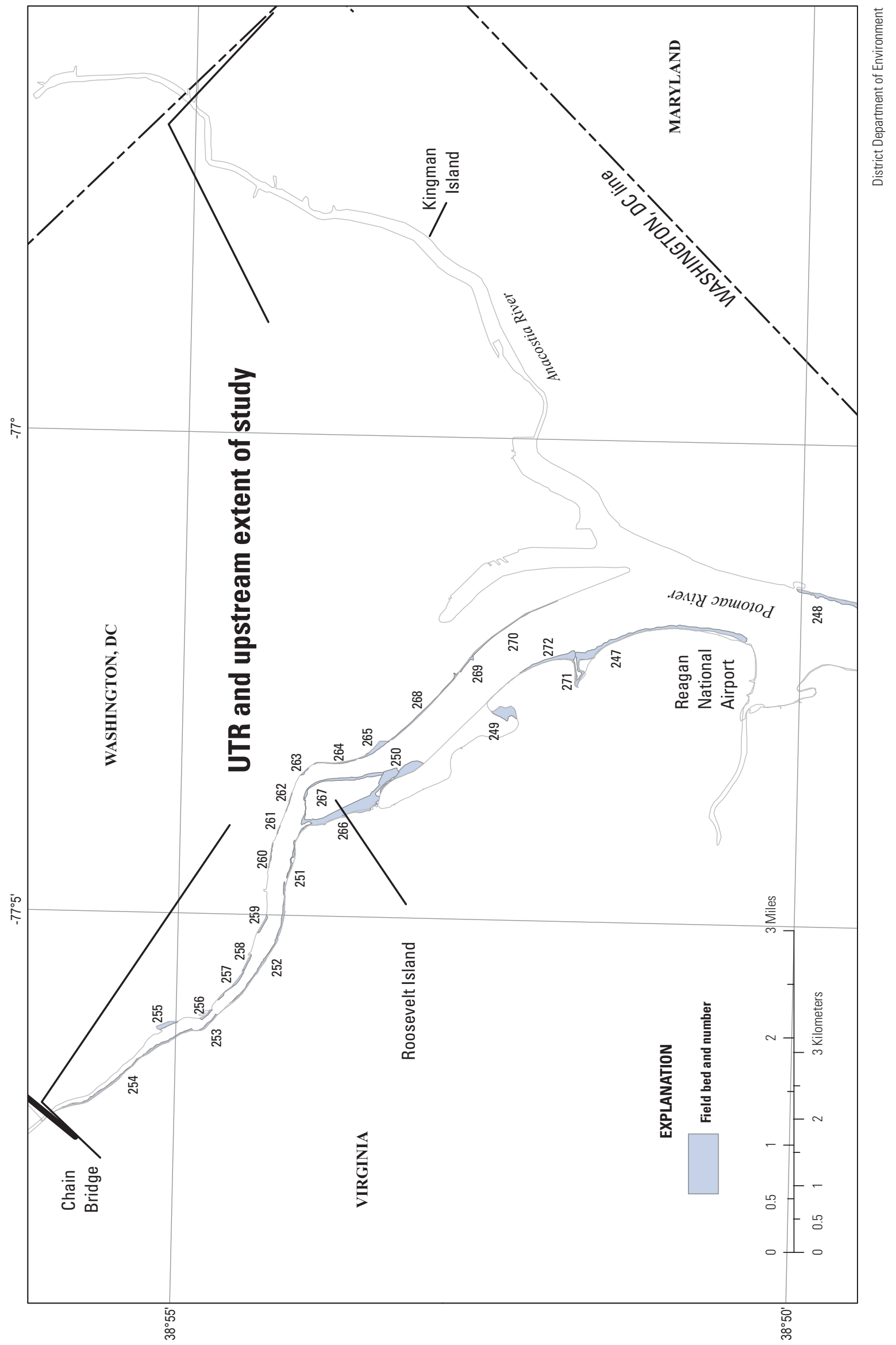




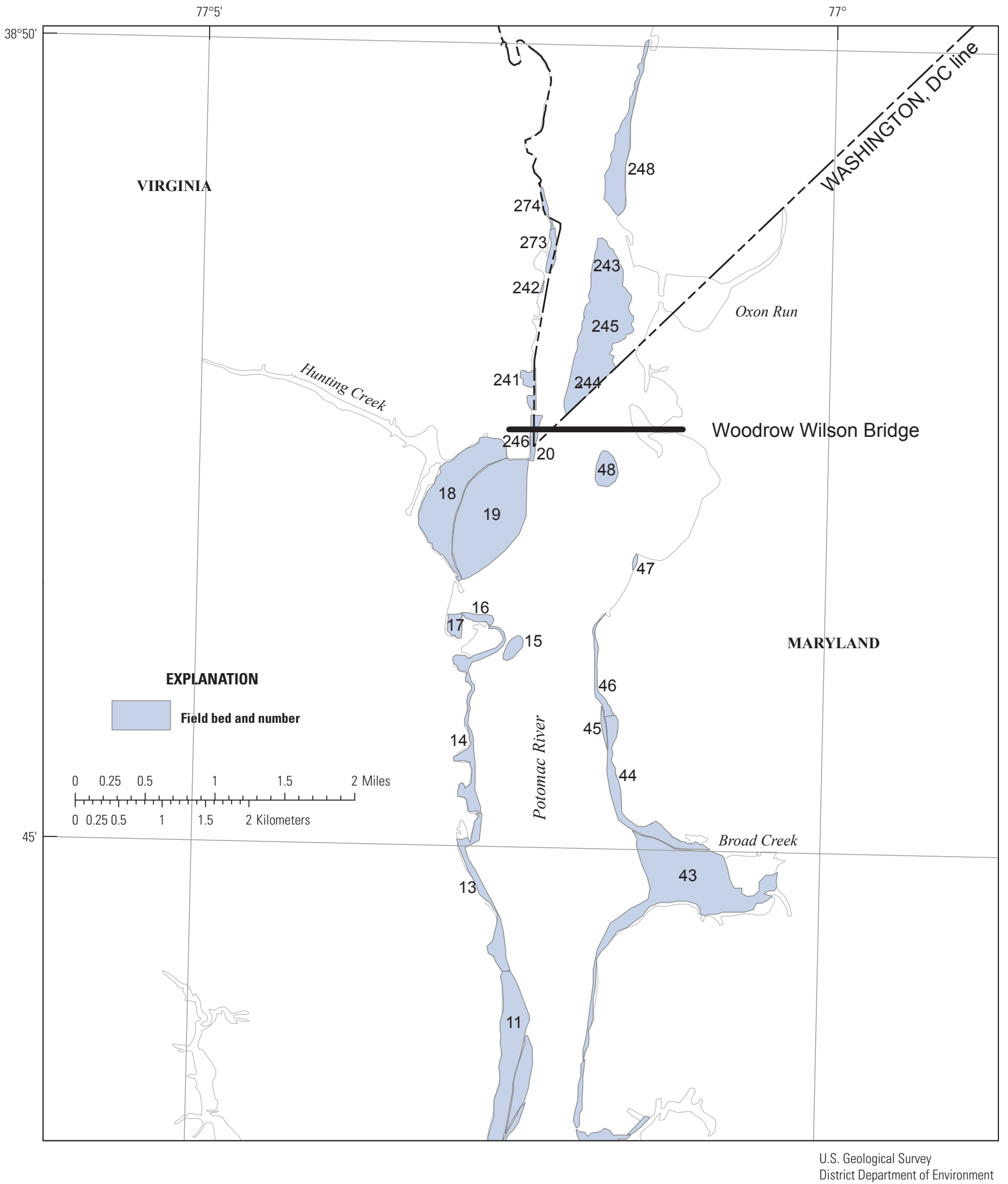

Figure 6. Location of each field bed in a continuous shoreline survey from Washington, D.C., to Broad Creek, Md., 2007. 


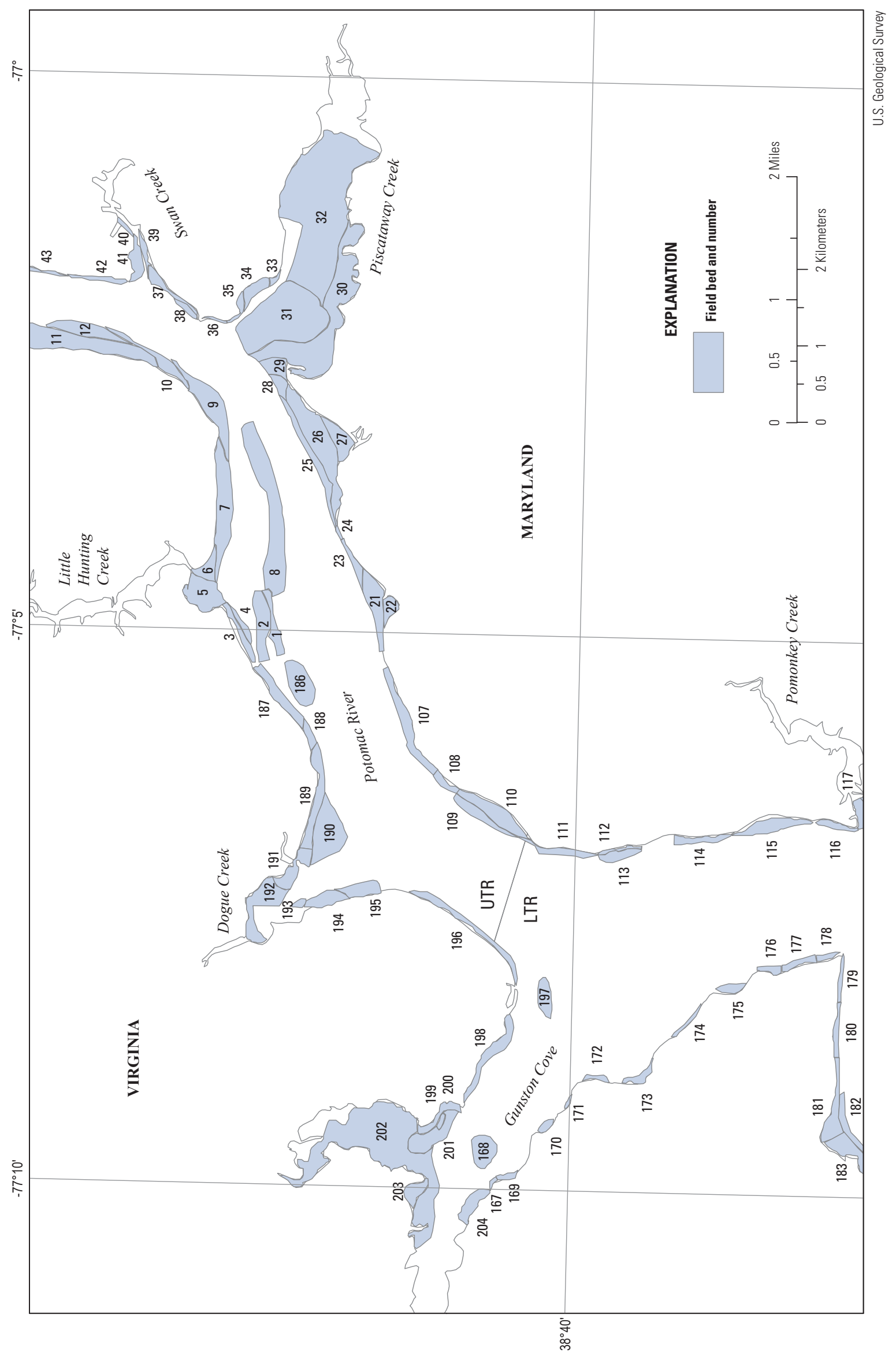

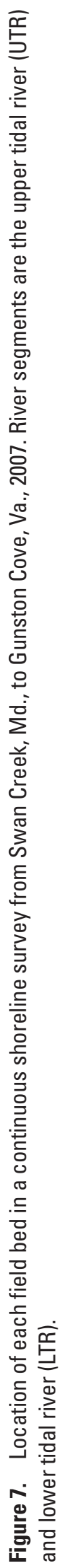




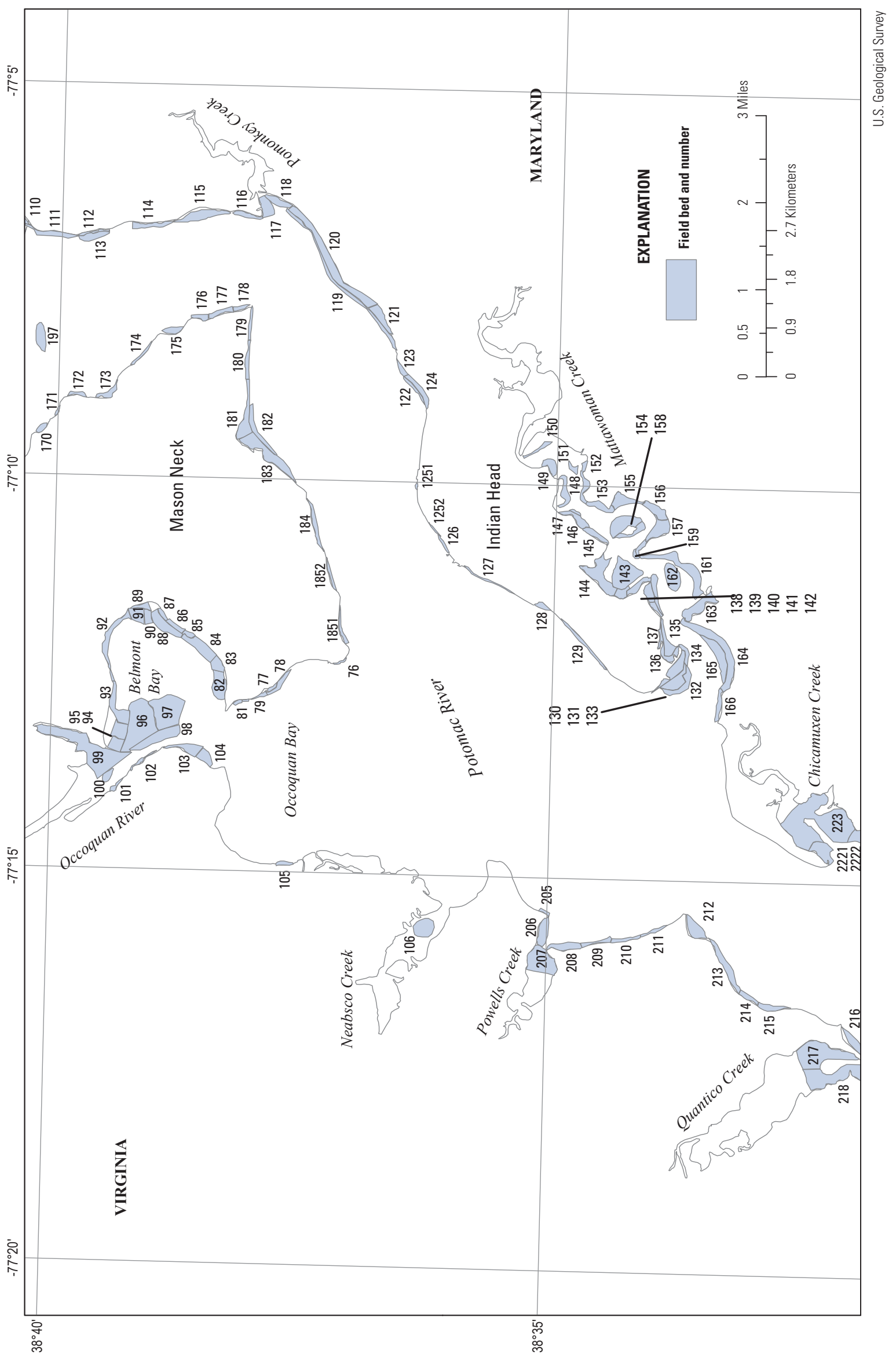

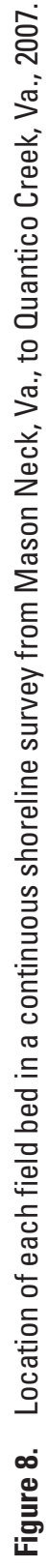




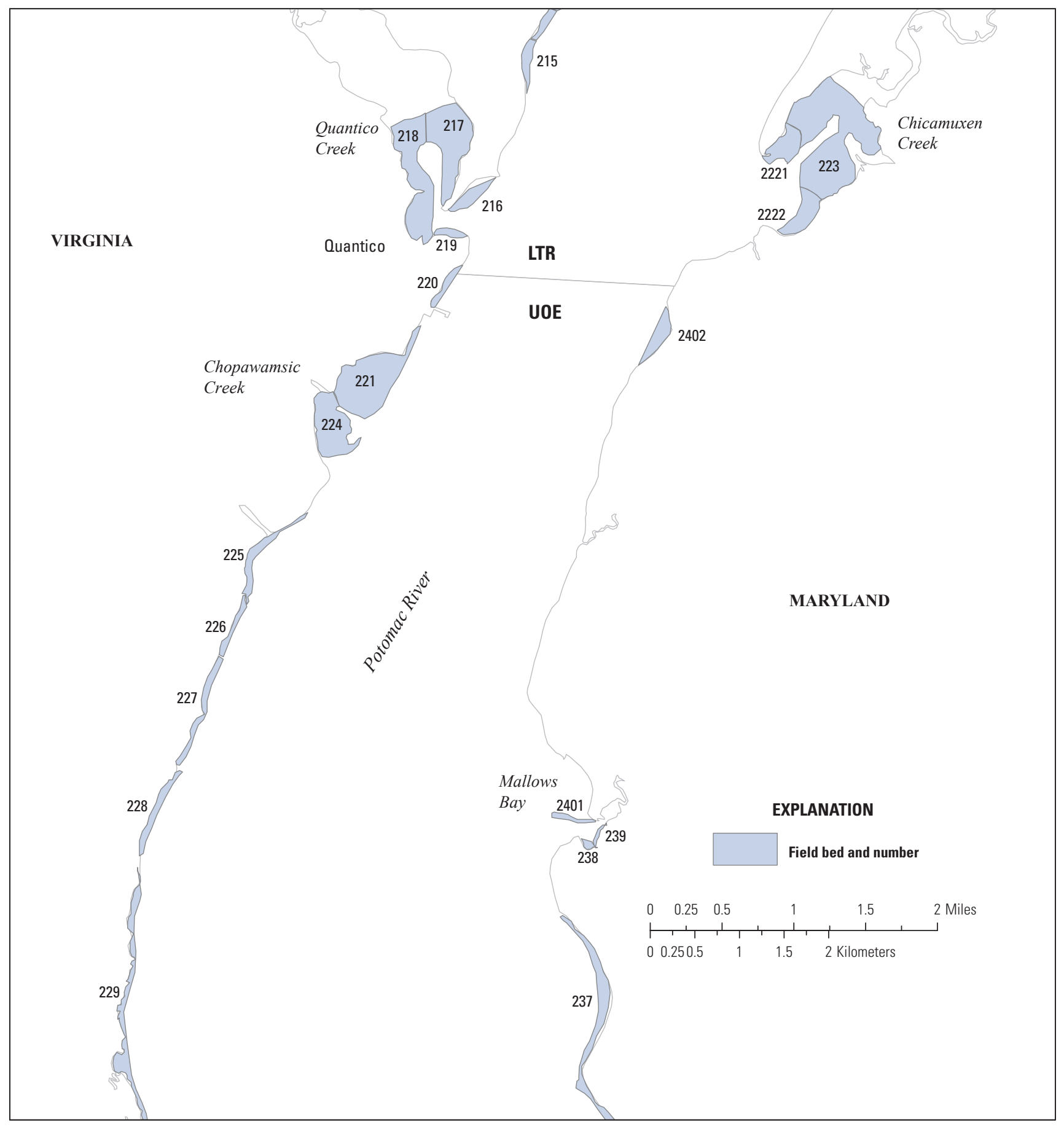

U.S. Geological Survey

Figure 9. Location of each field bed in a continuous shoreline survey near Quantico, Va., and Mallows Bay, Md., 2007. River segments are the lower tidal river (LTR) and upper oligohaline estuary (UOE). 


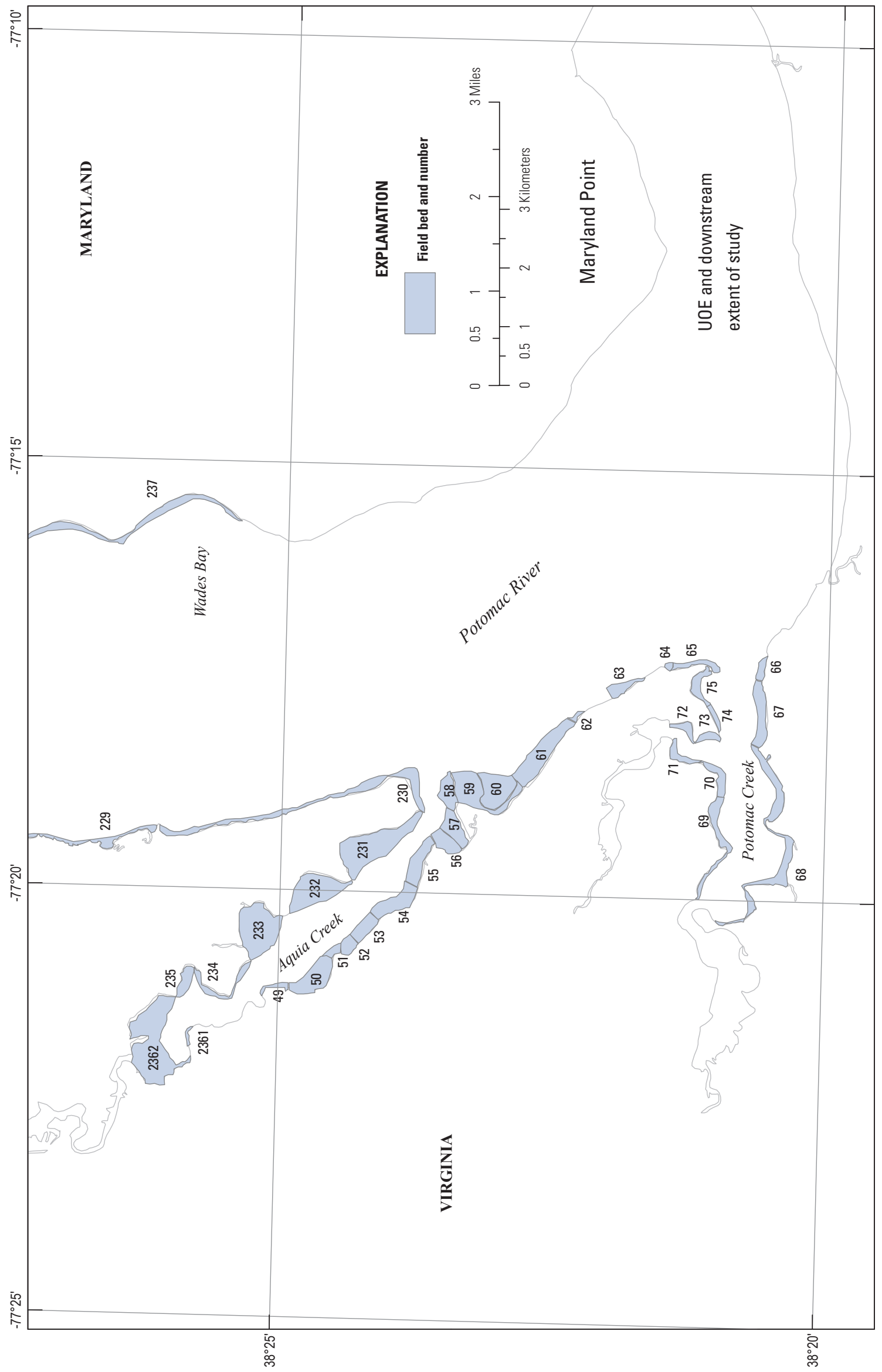

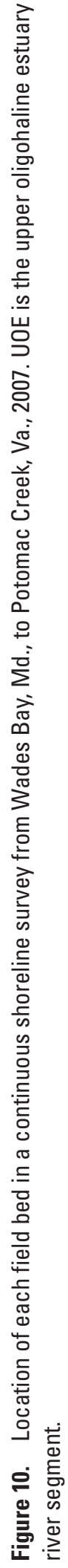




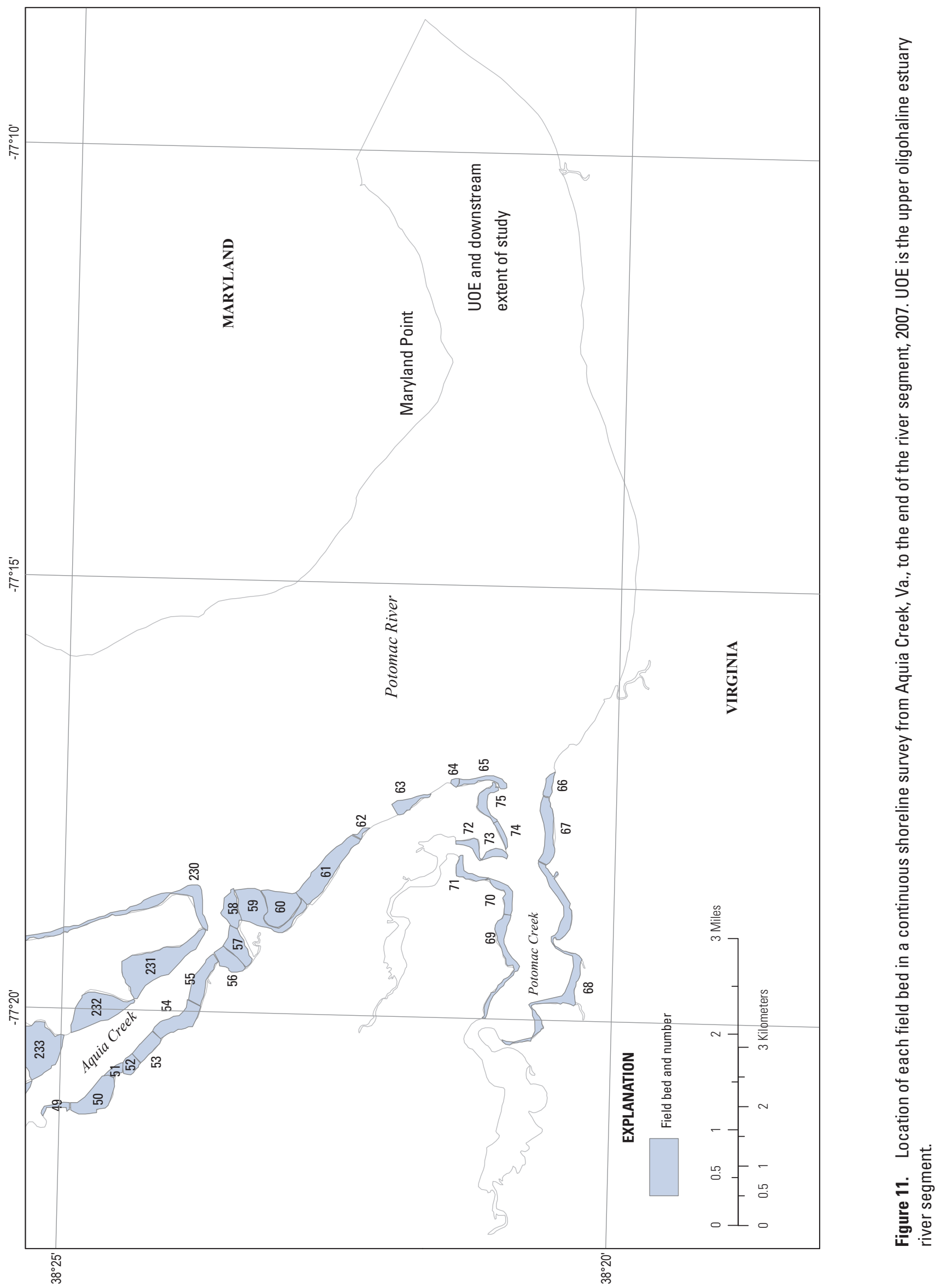




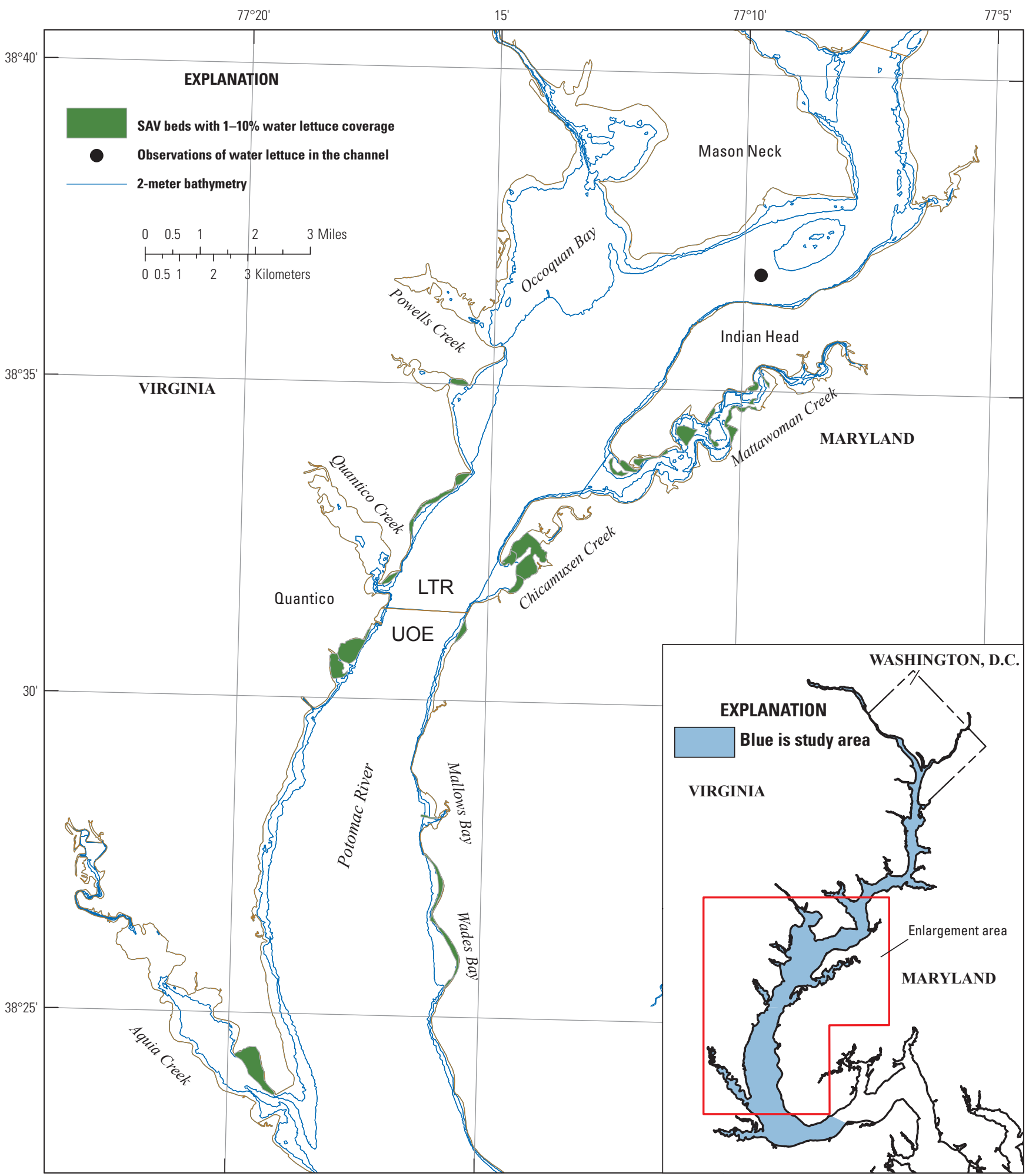

Figure 12. Distribution of water lettuce in the tidal Potomac River between Mason Neck and Aquia Creek, Va., 2007. LTR, lower tidal river; SAV, submersed aquatic vegetation; UOE, upper oligohaline estuary; \%, percent. 


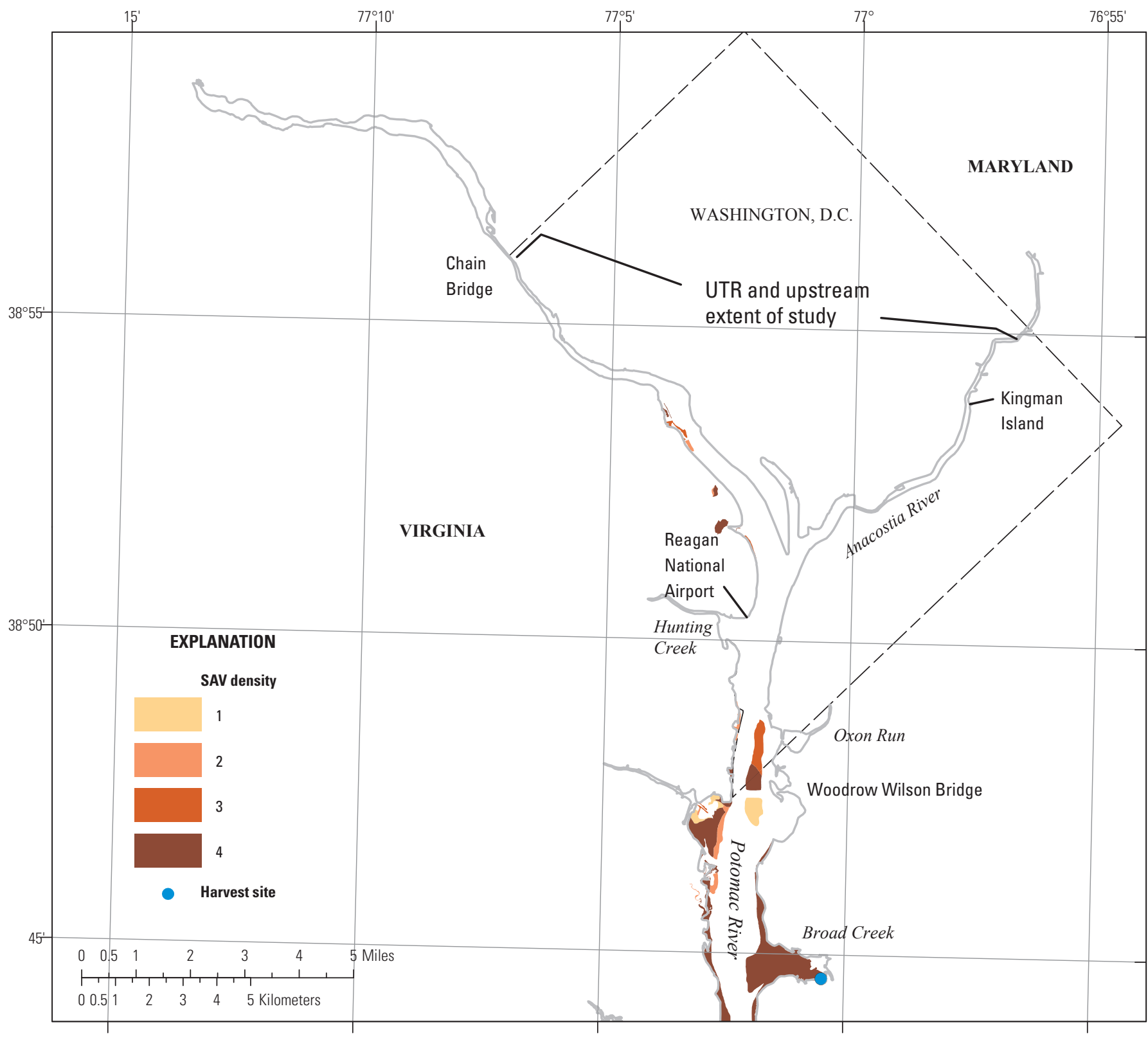

Note: SAV beds shown in figures 13,14 , and 15 were delineated by

Virginia Institute of Marine Science VIMS based on aerial photographs, then digitized and classified for ground cover density. Density was determined using the Crown Density Scale adapted from Paine (1981). Bed densities range from one to four with one corresponding to less than $10 \%$ vegetation coverage, two representing between 10 and $40 \%$ coverage, three representing between 41 and $70 \%$ coverage and four corresponding to 71 to $100 \%$ coverage.

Figure 13. Distribution and density of submersed aquatic vegetation (SAV) and the locations of the aquatic plant management harvest sites in the tidal Potomac River from Washington, D.C., to Broad Creek, Md., 2007. UTR is the upper tidal river study segment. 


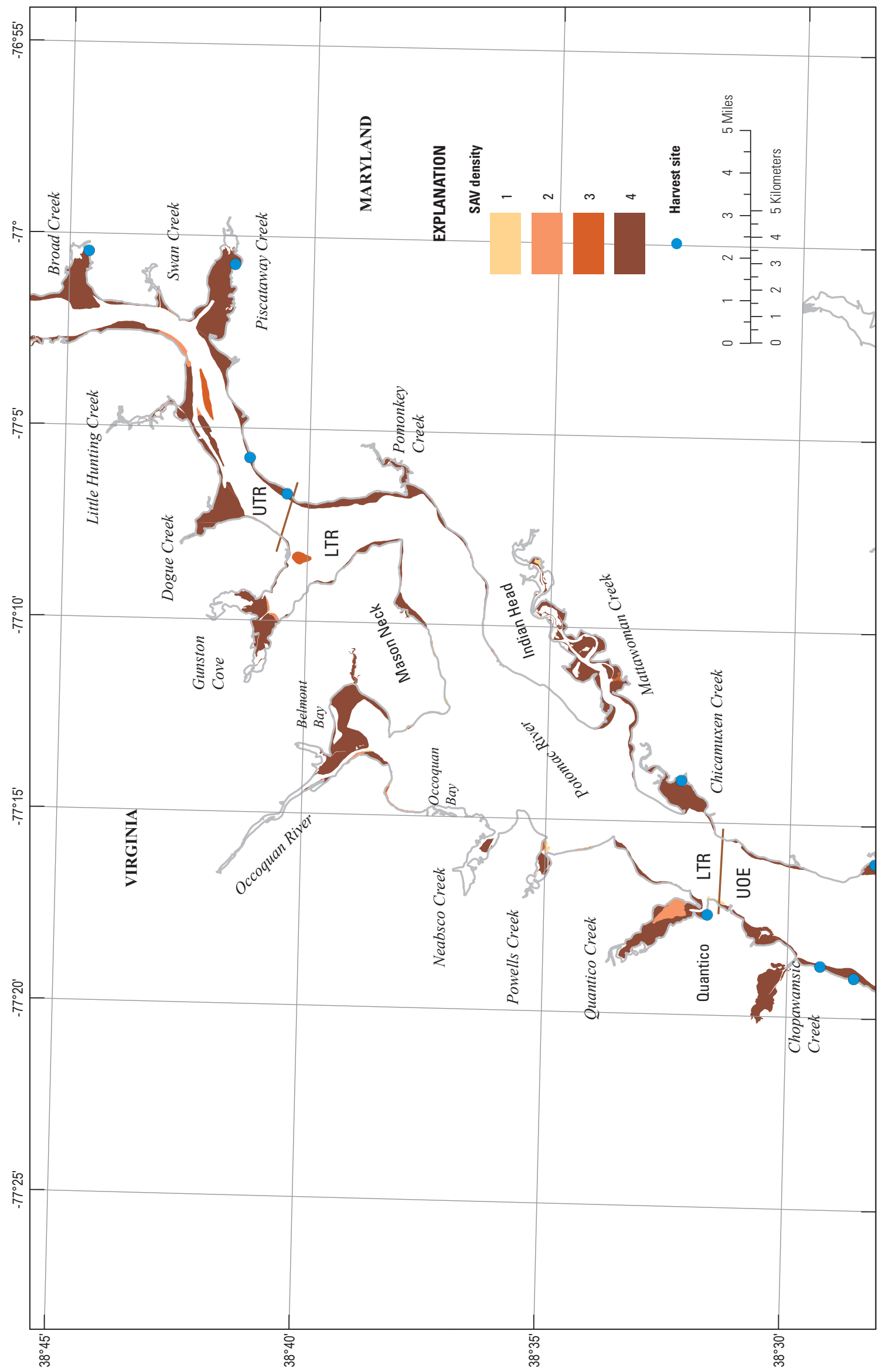

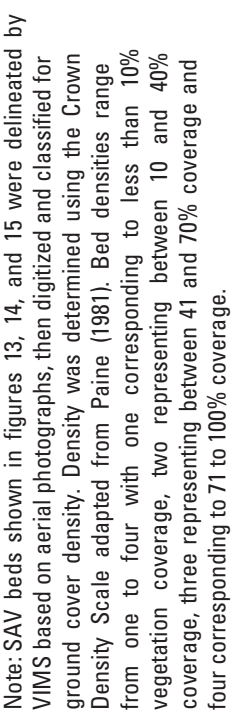

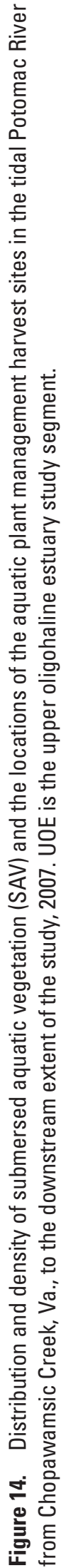



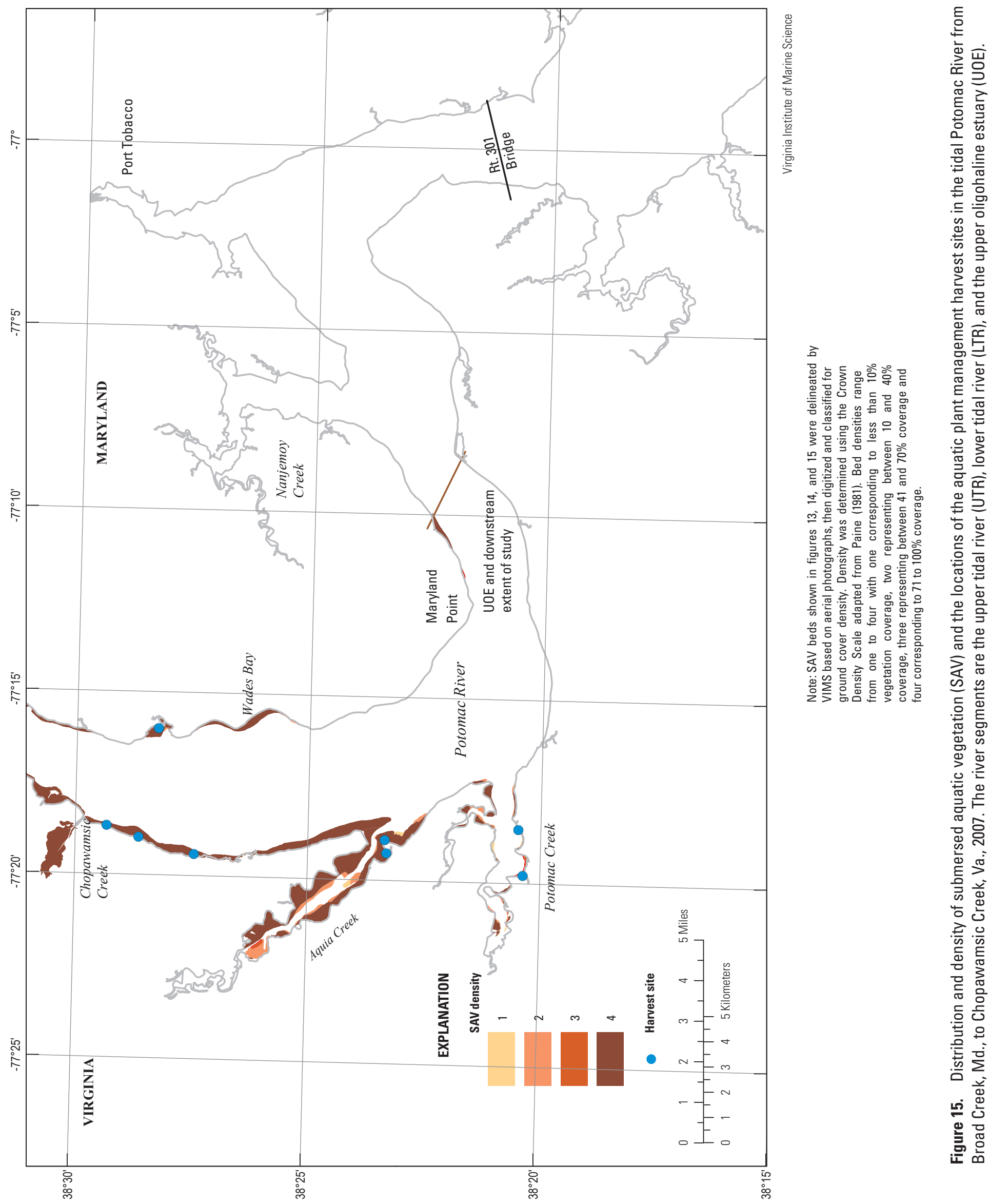


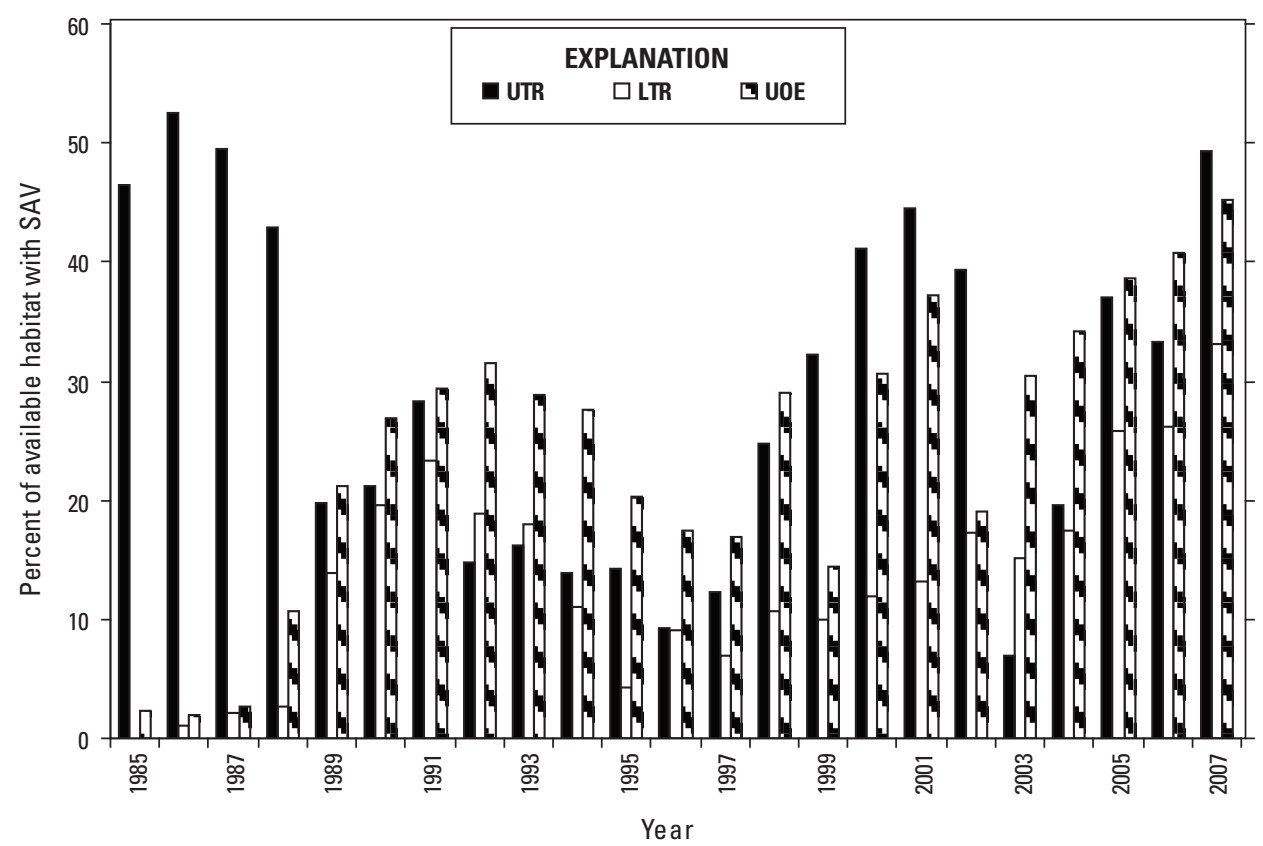

Figure 16. Percent of available habitat (area less than 2 meters in depth) that was vegetated in each river segment (UTR, LTR, and UOE) from 1985 to 2007. The UTR, LTR, and UOE have 2,956, 5,173, and 3,355 hectares of available habitat, respectively. UTR, upper tidal river; LTR, lower tidal river; UOE, upper oligohaline estuary; SAV, submersed aquatic vegetation.

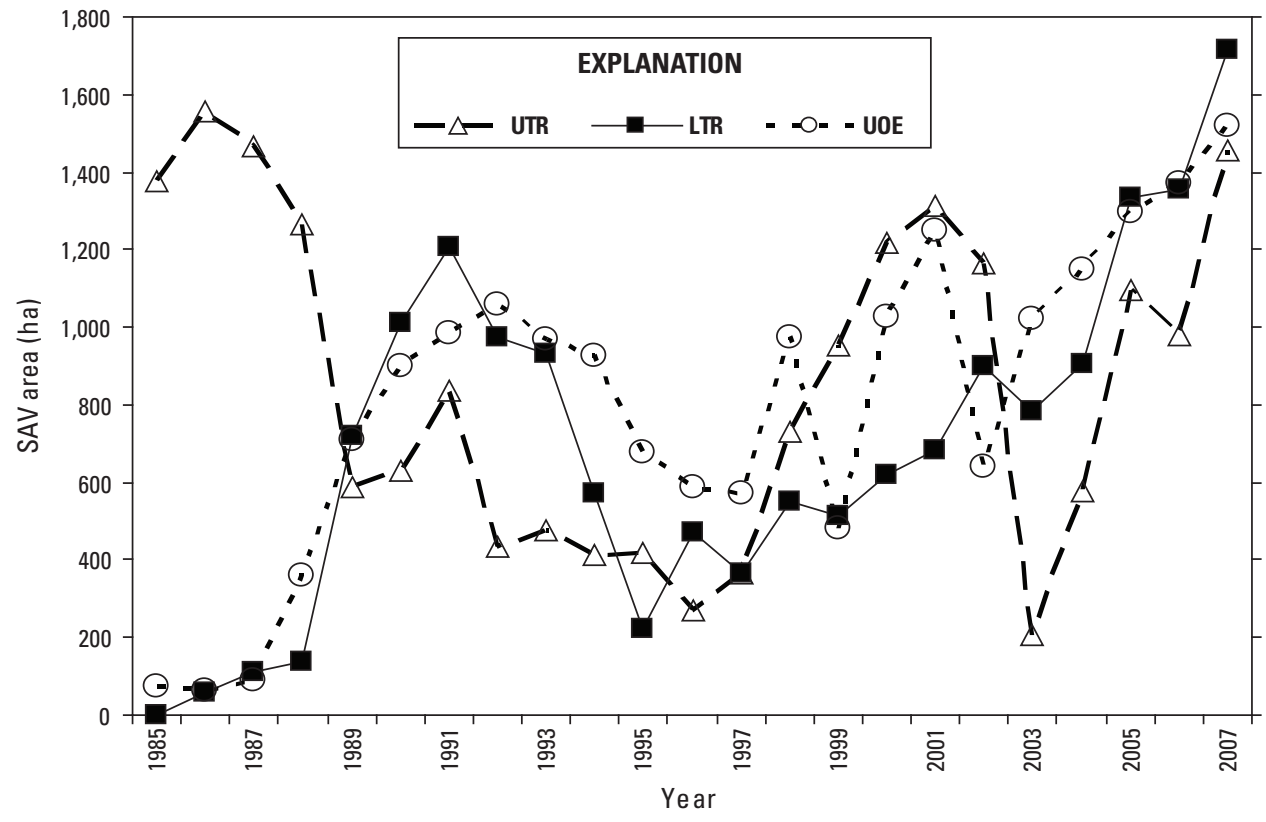

Figure 17. Area occupied by submersed aquatic vegetation (SAV) for each river segment (UTR, LTR, and UOE) from 1985 to 2007. SAV area from Virginia Institute of Marine Science (Orth and others, 2008) except from U.S. Geological Survey in 1988 (Rybicki and Landwehr, 2007). UTR, upper tidal river; LTR, lower tidal river; UOE, upper oligohaline estuary; ha, hectare. 

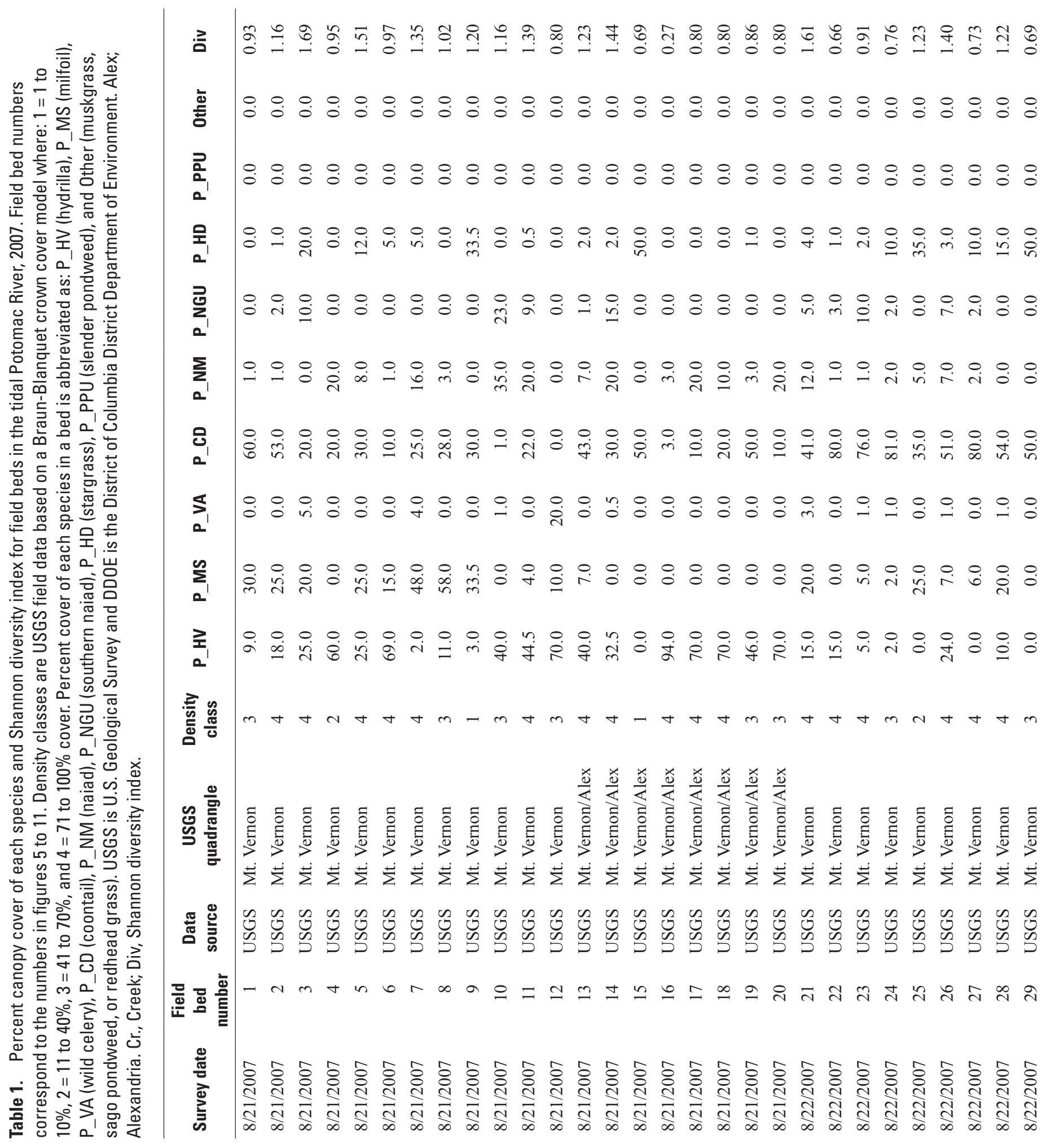


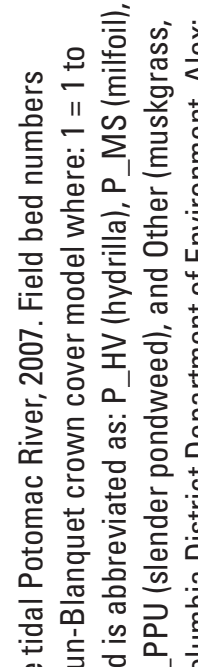

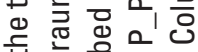

絮的

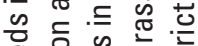

응 응 훈

믕

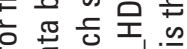

$\times$ 중

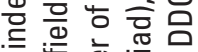

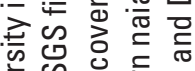

कั

긍 ఏ

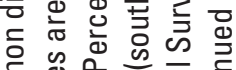

\&

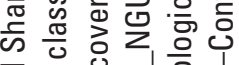

두일

\%

엉

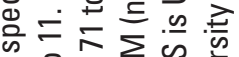

요에에

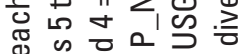

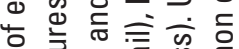

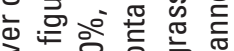

完.

文事过焉交

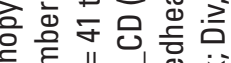

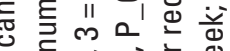

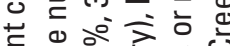

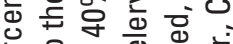
웅워웡

믄 $=$ 은 흠 흔

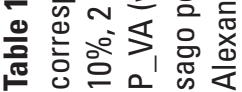

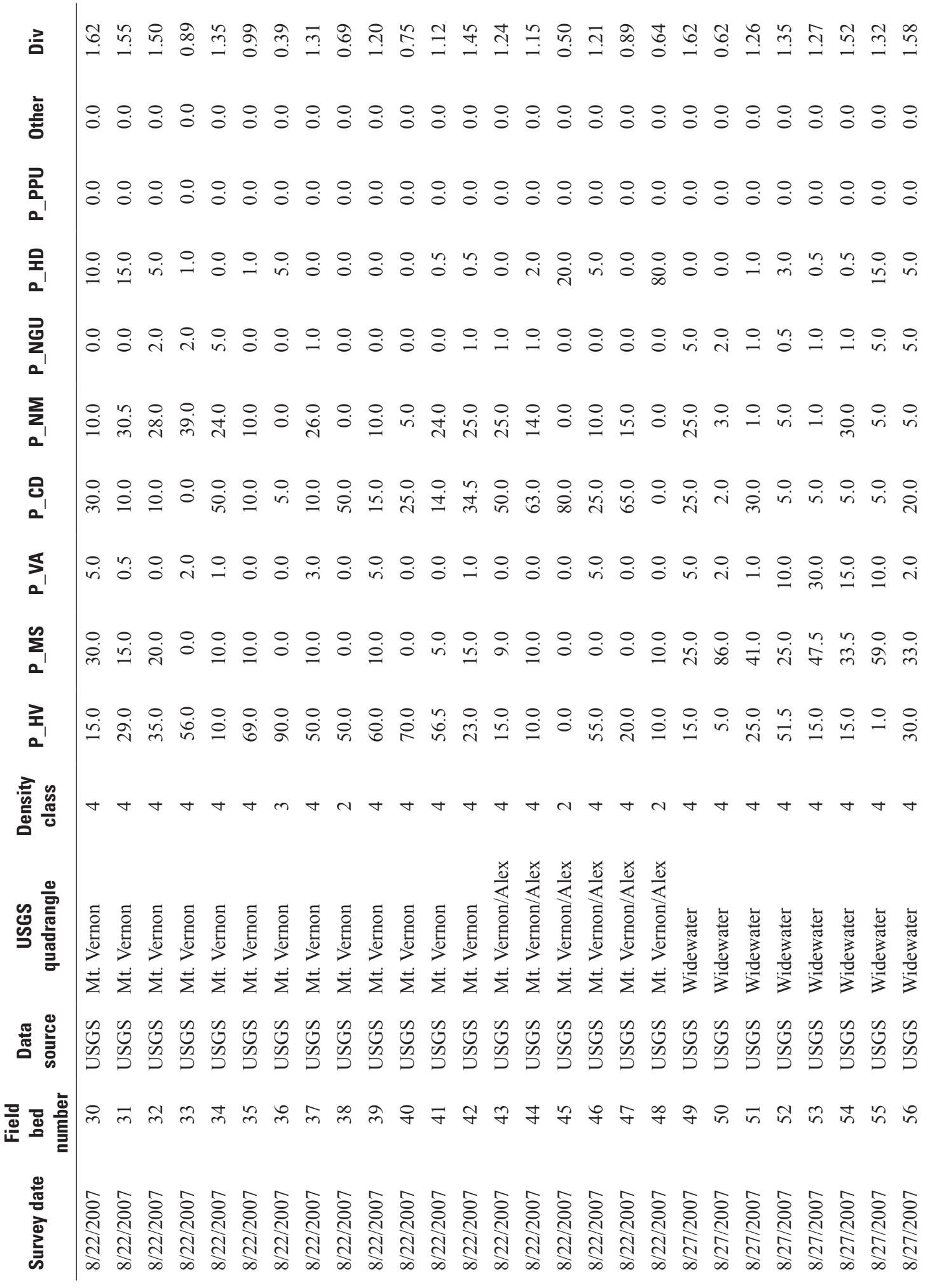




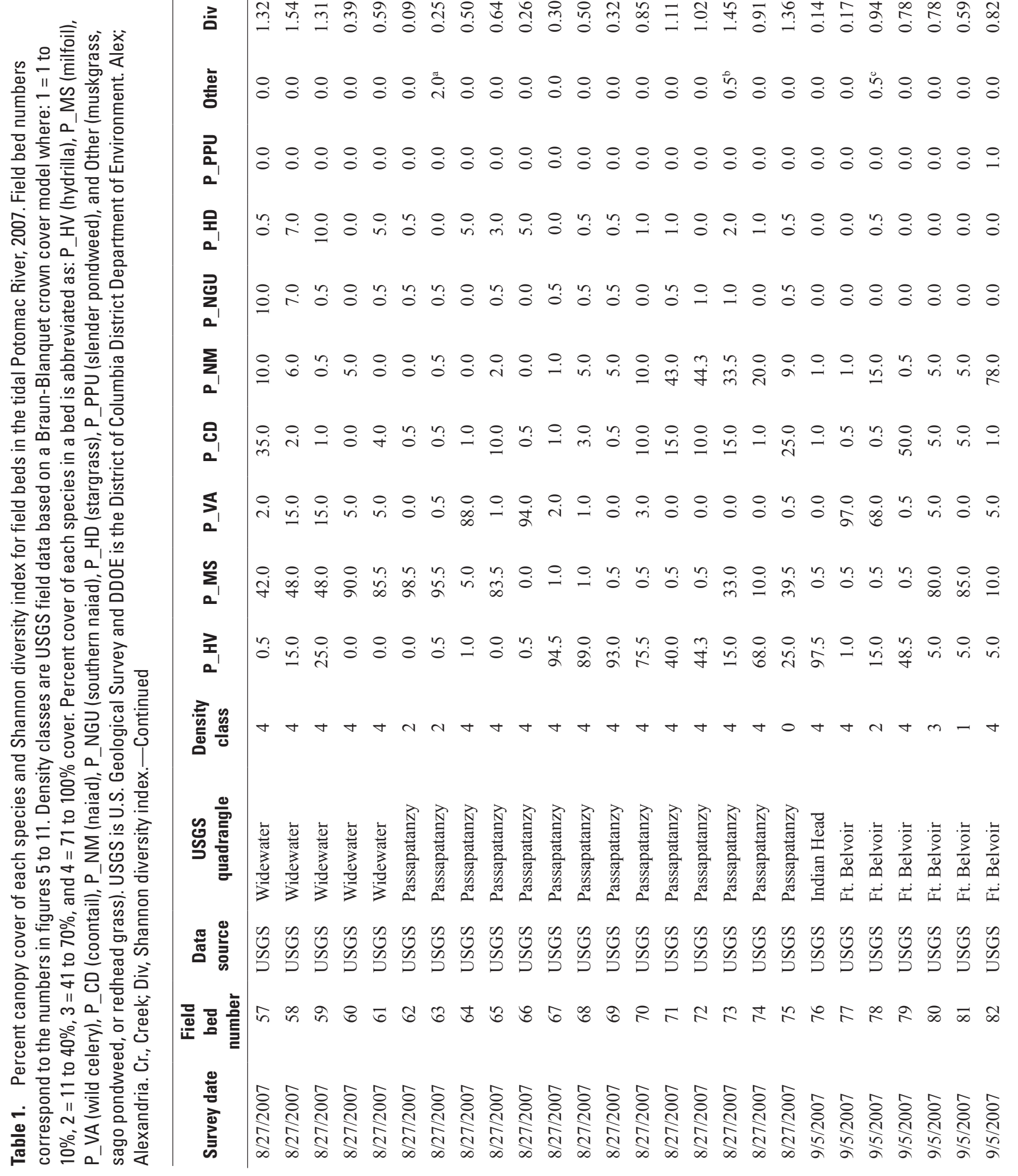




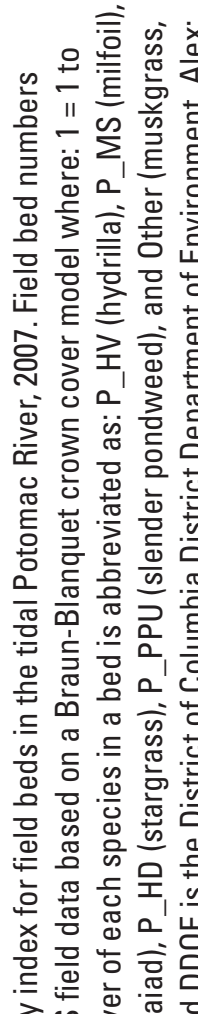

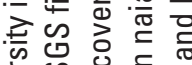

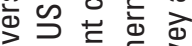
응 d

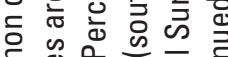

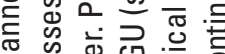
匹 范过 匹

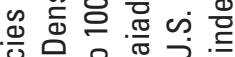

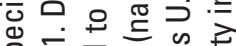
을 전

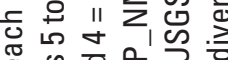

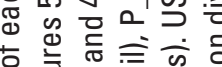

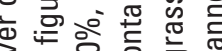

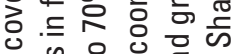
긍

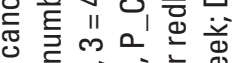
ป बें

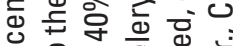
헝ㅇㅇ웡 은드음

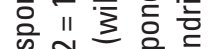

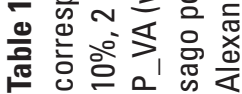

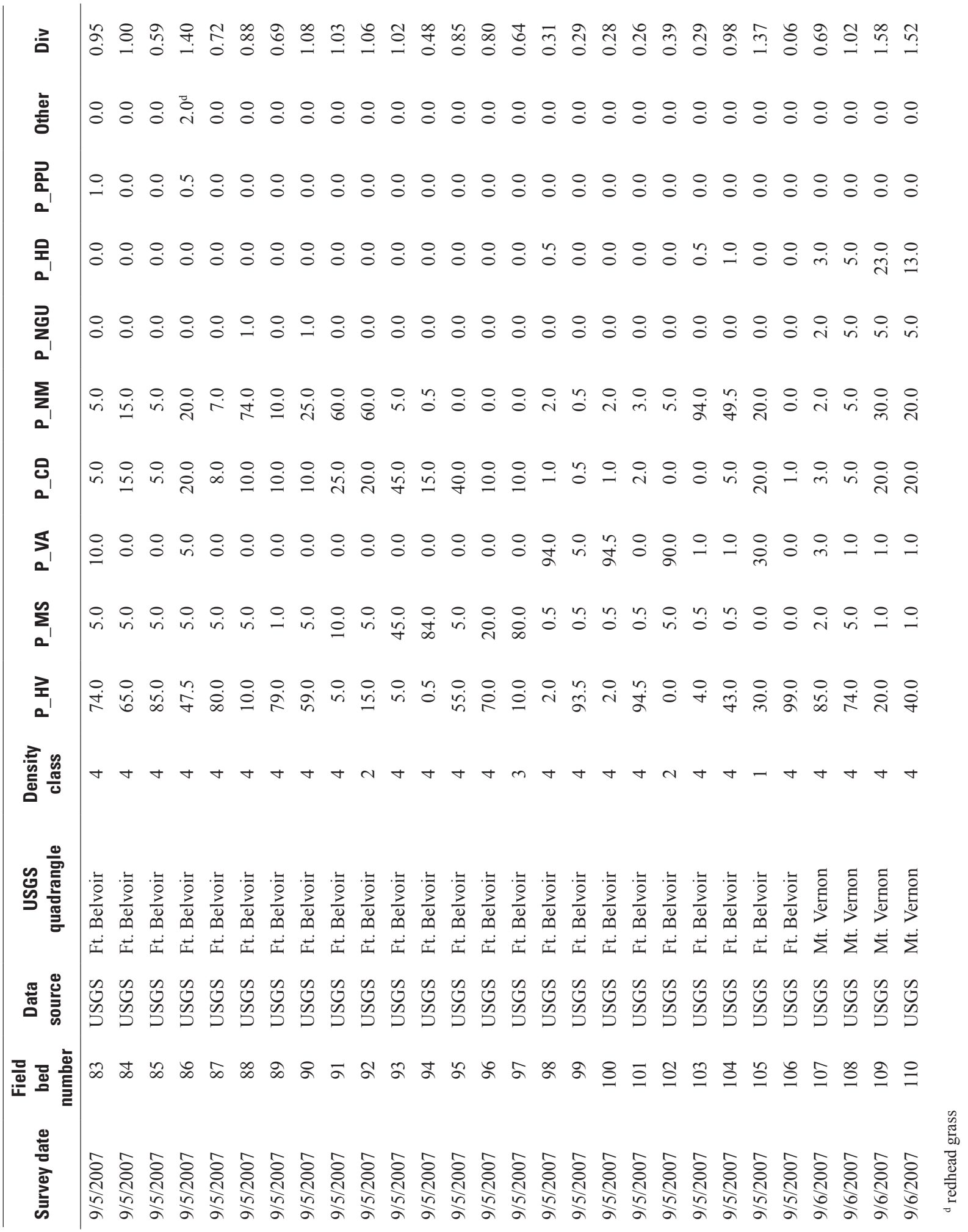




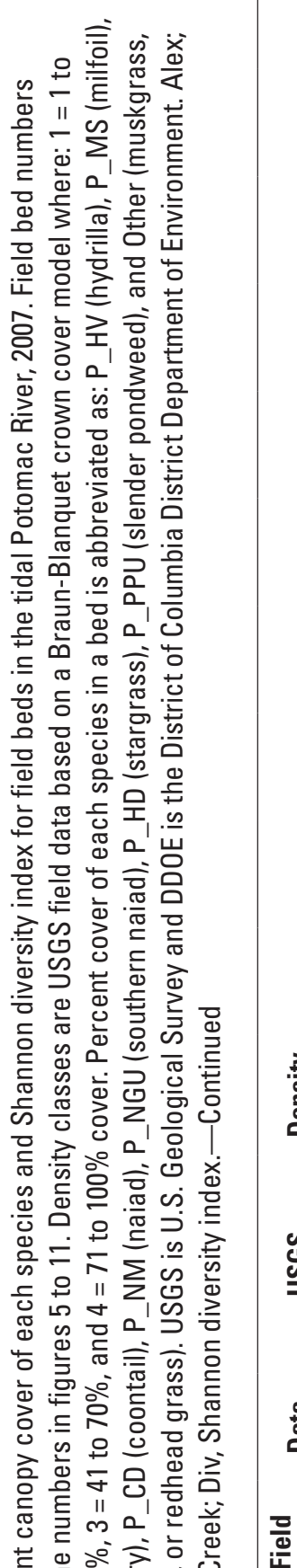

: $\mid$ ก 龸 衣

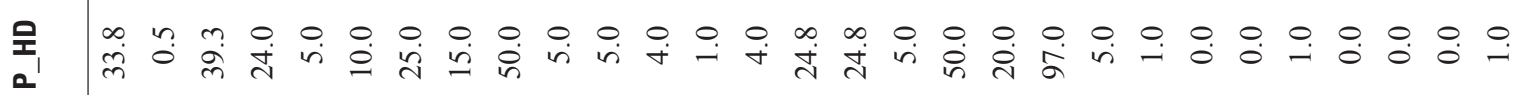

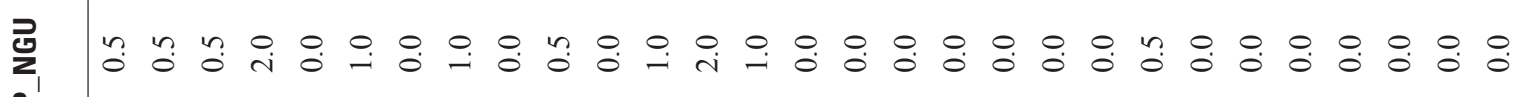

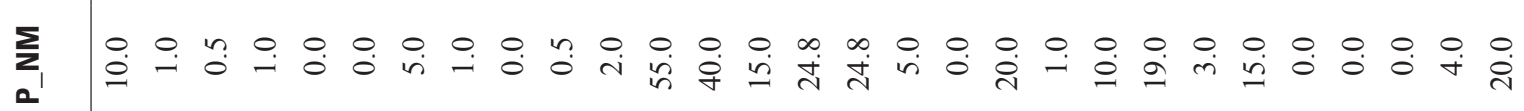

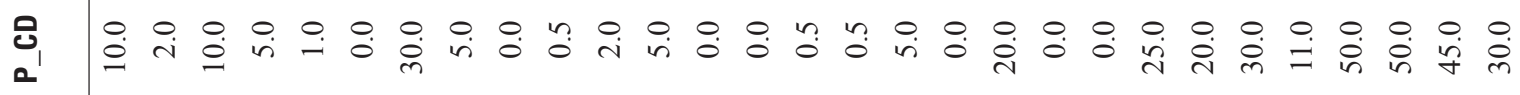

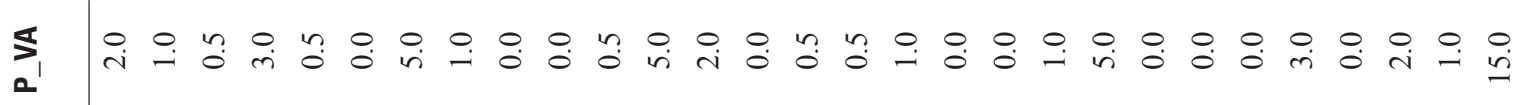

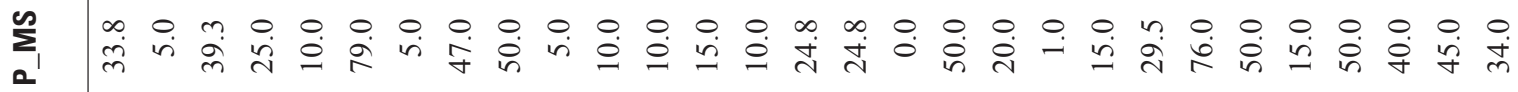

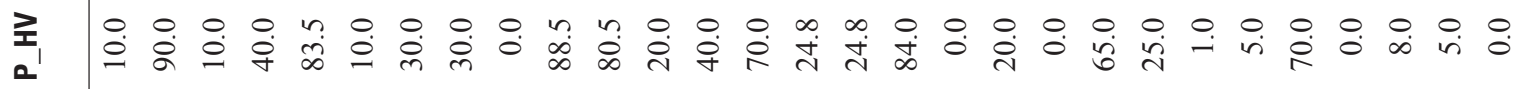

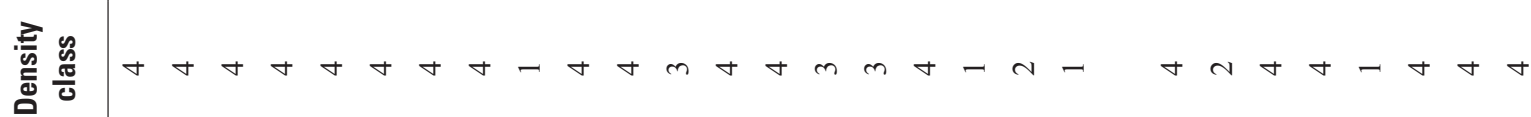

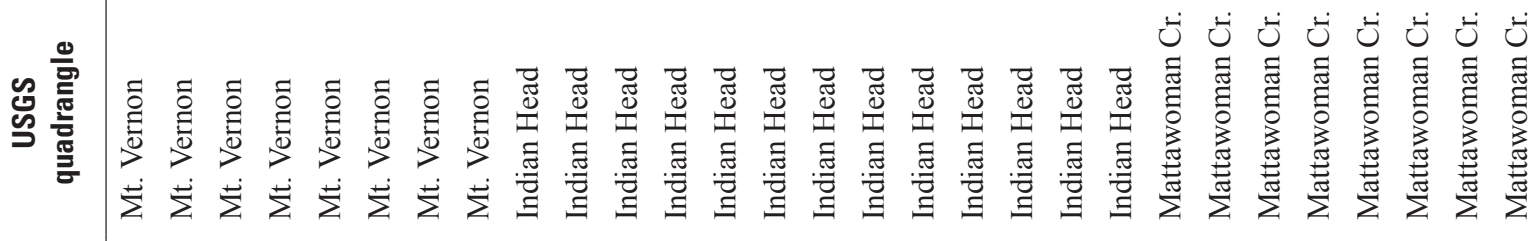

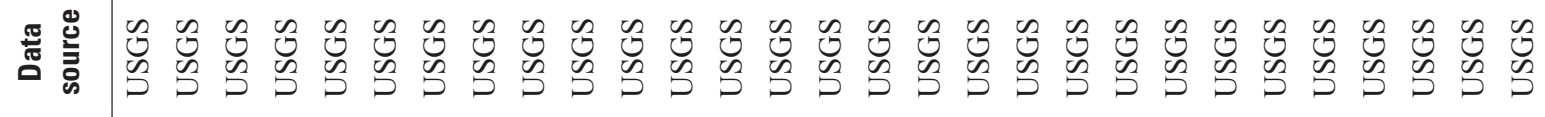

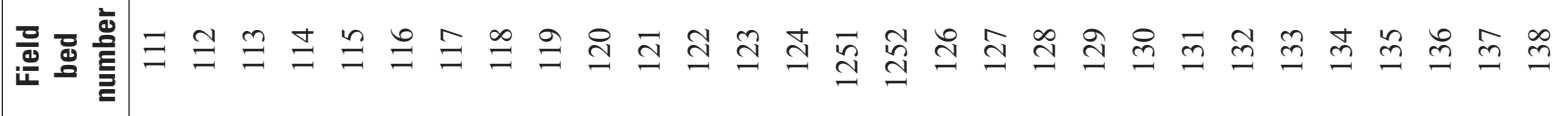

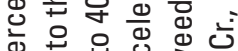

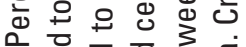
듣을 을 -

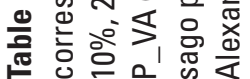




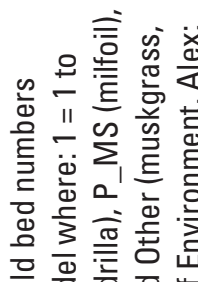

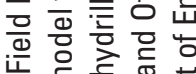

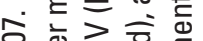

N

证

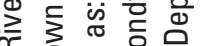

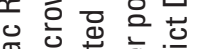

需

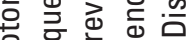

드응

즘 $\frac{\pi}{0}$

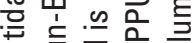

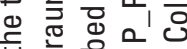

吉市穴它

$\therefore \approx$

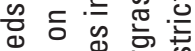

웅 은

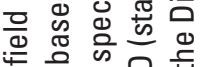

흔 둔오 호

要

음 등 후음

.

武的要

닐

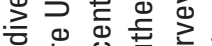

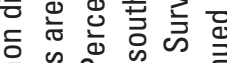

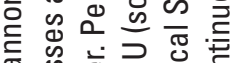

空

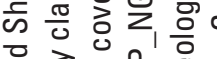

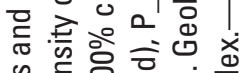

\& 흥. 흥

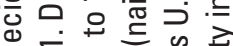

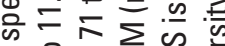

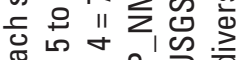

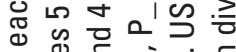

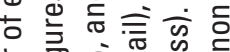

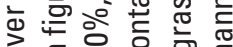

겅. 훙휴

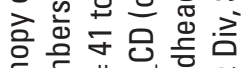

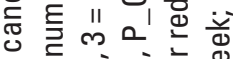

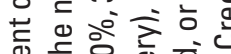

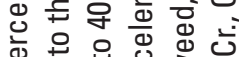

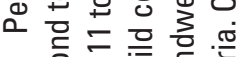

응 플

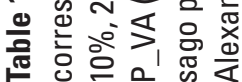

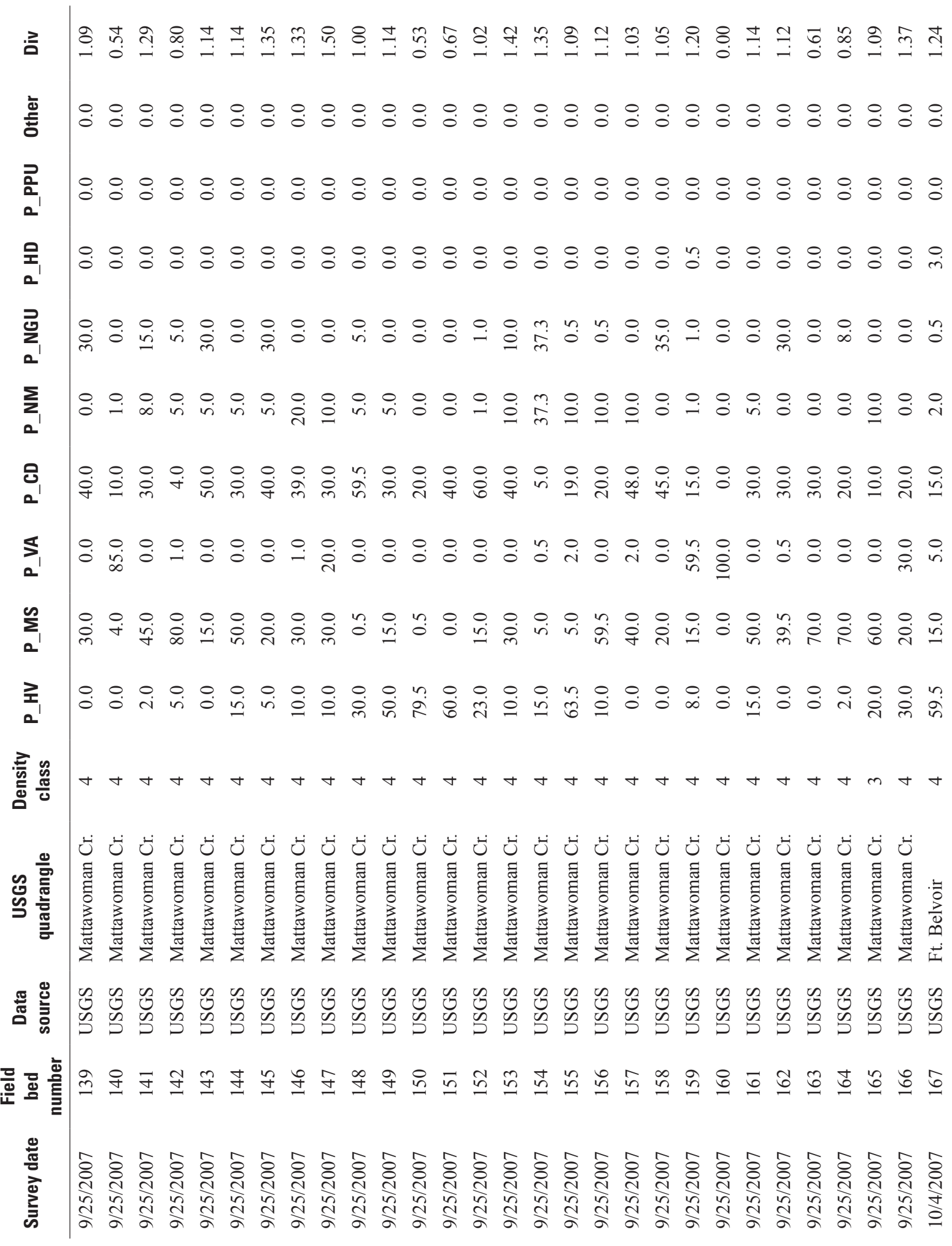



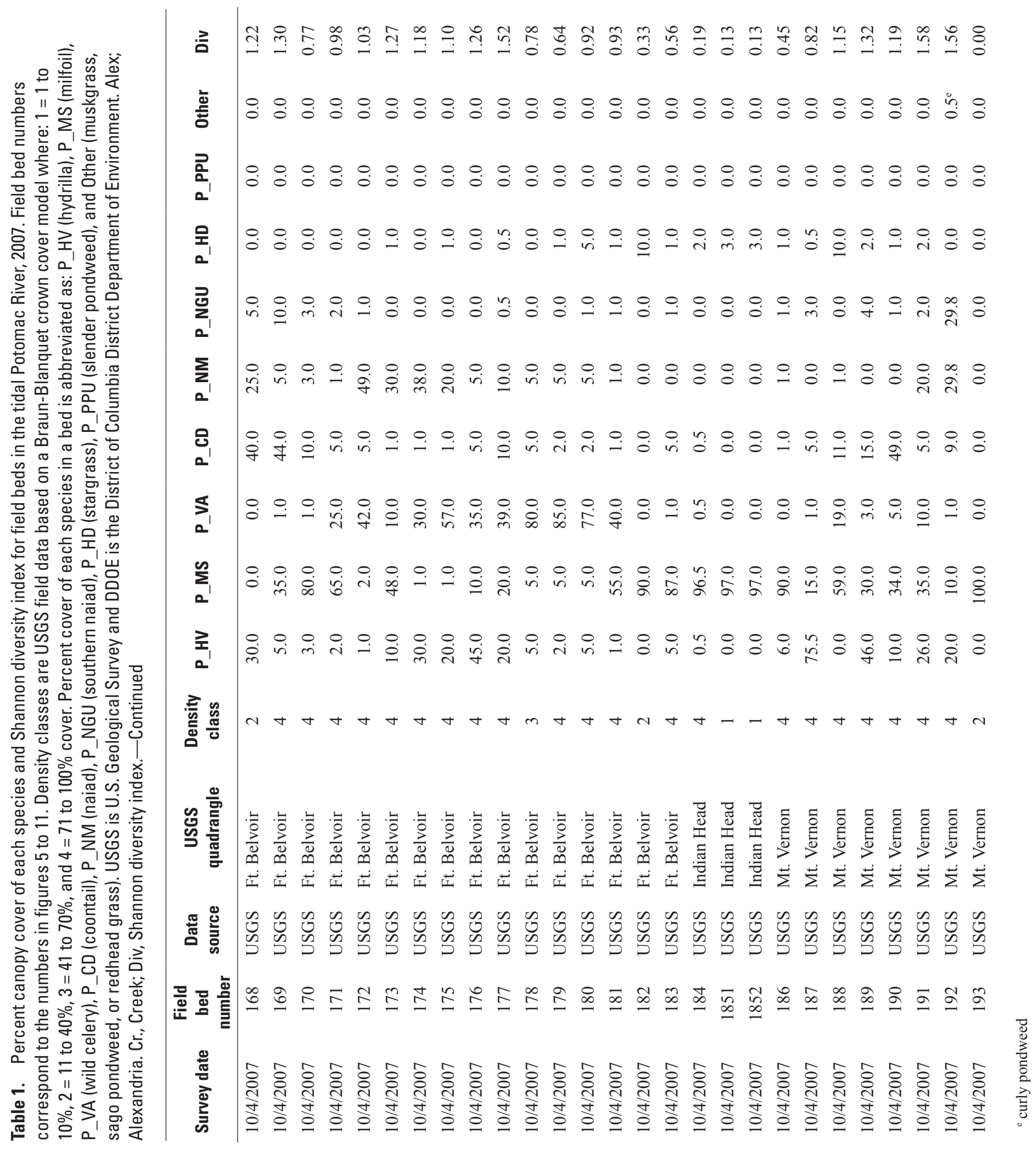


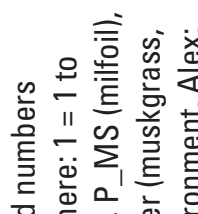

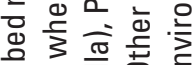

응ㅎㅁ

은 은 홀든

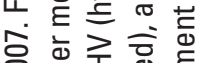

이오

군인

j is क्षे

u 잉 문

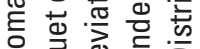

응 흥 क

즘 $\frac{\pi}{2}$

증 뜨몸

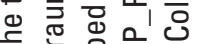

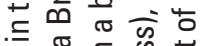

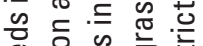

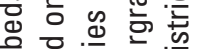

응 \&

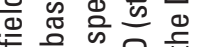

흥퓨 든오 호

증 元口岩

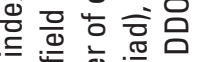

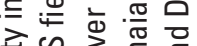

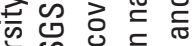

ఏ

잉 仓

등 凹

它

क $\frac{\pi}{0}$ 인응

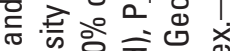

\& ᄃ

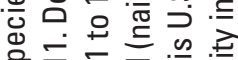

品 $=\frac{1}{\Sigma} \frac{\infty}{\omega}$

듄워

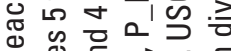

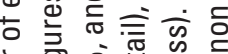

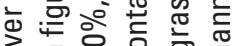

응ㅇㅇ 흔

心의 유

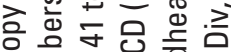

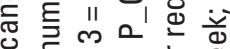

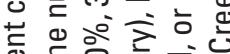

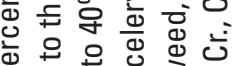

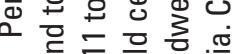

응 11 妾 등

- के v

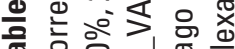

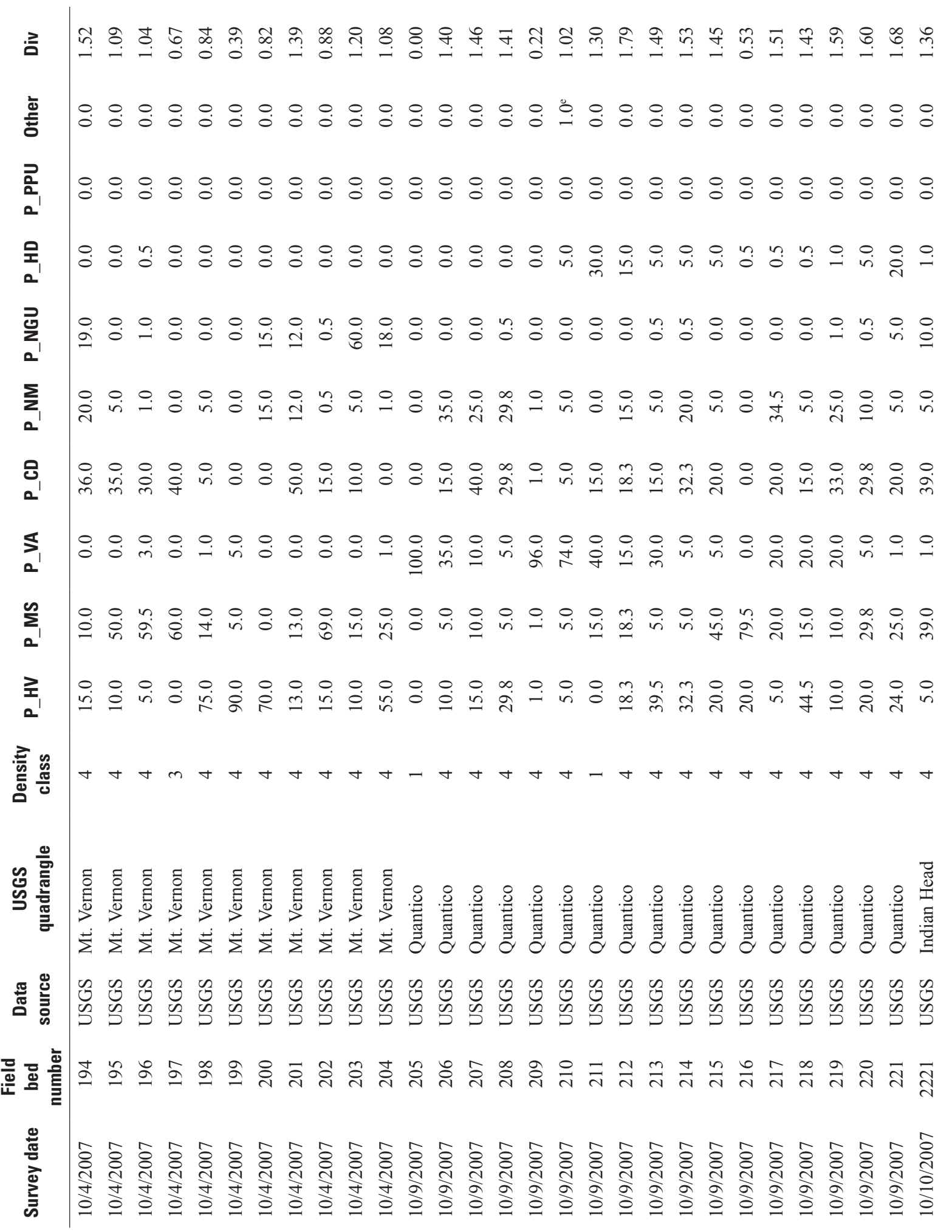




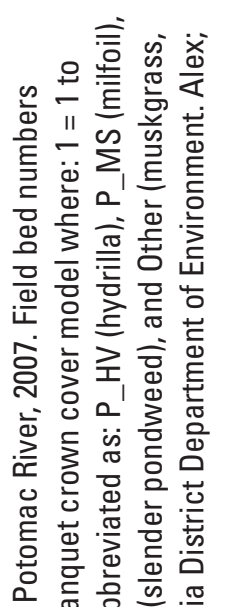

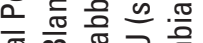

증

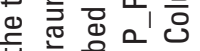

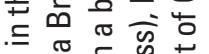

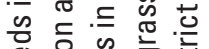

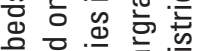

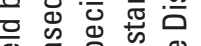

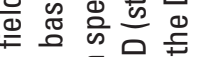

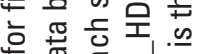

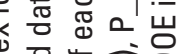

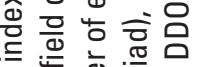

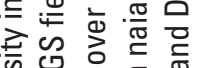

क्ष

ఎ

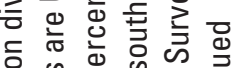

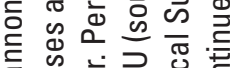

元

的 元

志

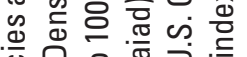

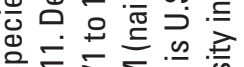

क

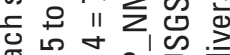

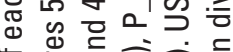

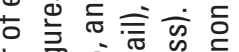

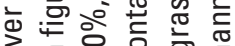

응ㅇㅇㅎㅇ 흔

ज。유

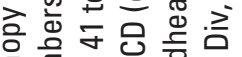

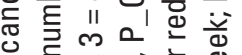

䒕产京交市

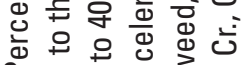

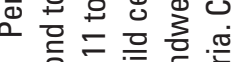
음 II

๑ d 는

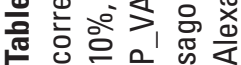

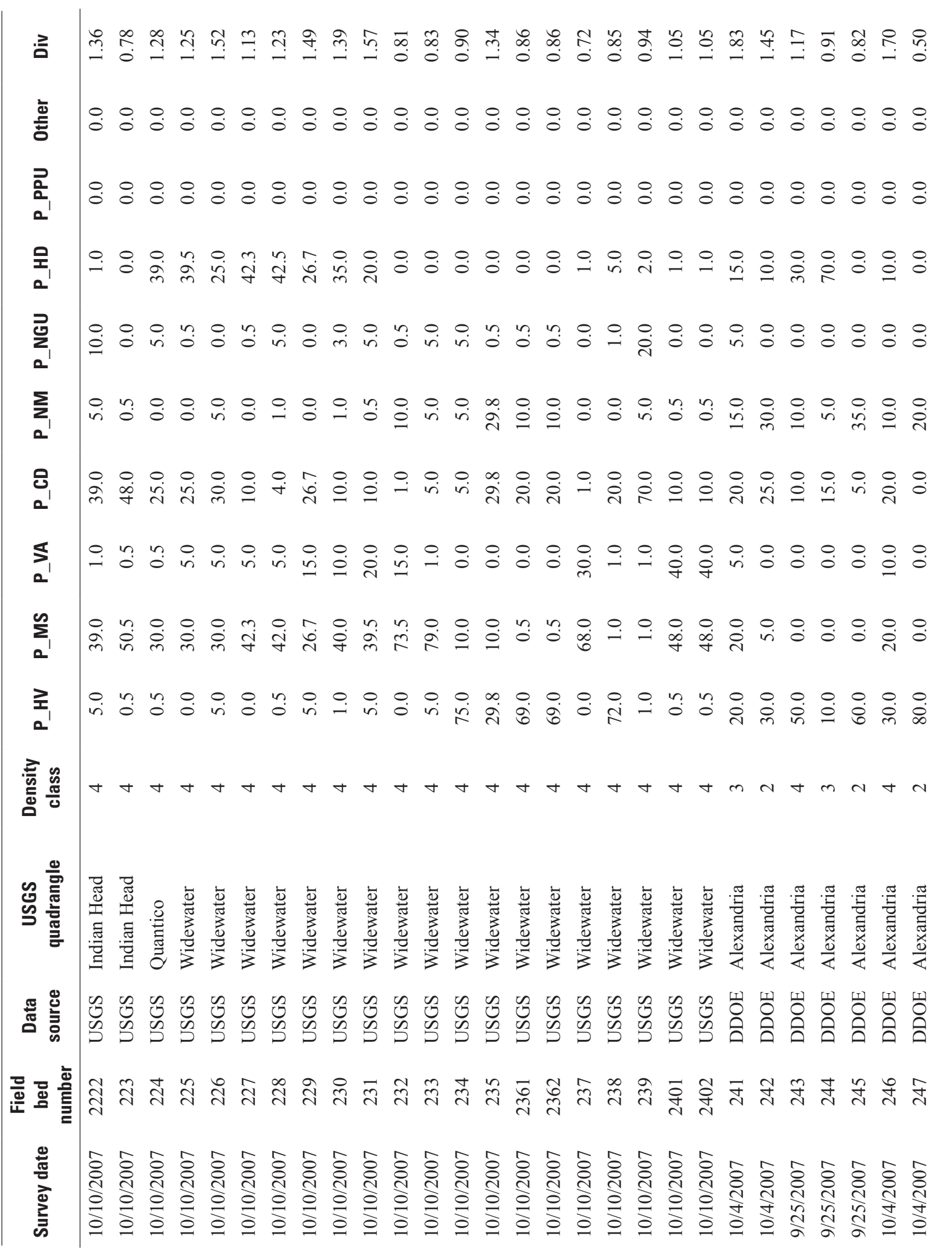




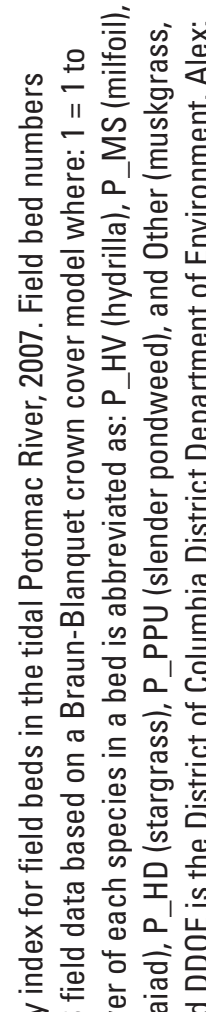

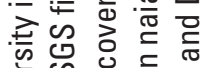

गे

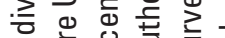

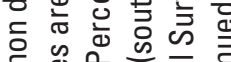

我西

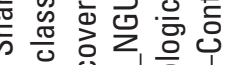

क 011

ส

웜

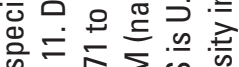

के

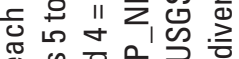

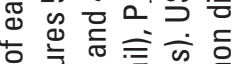

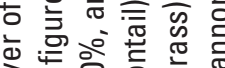

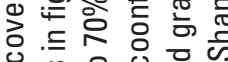

0. 응

言离东皆离

厓

등

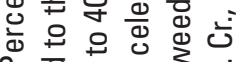

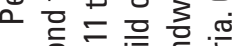

흔 11 灵

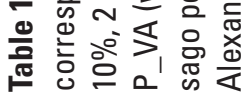

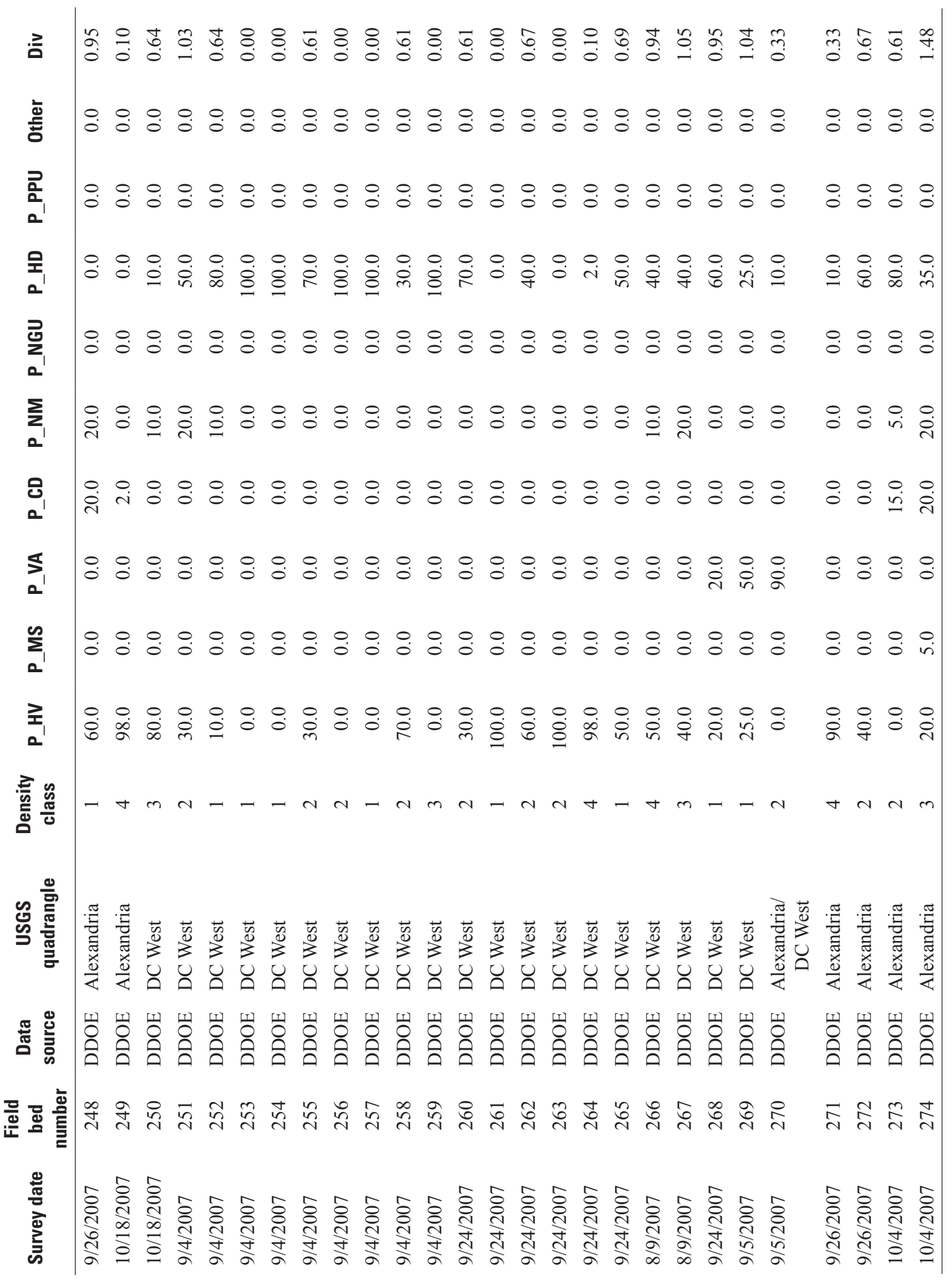


For additional information regarding this publication, contact: U.S. Geological Survey

National Research Program,

Eastern Region

432 National Center

Reston, VA 20192

http://water.usgs.gov/nrp/

Edited and prepared by:

USGS Science Publishing Network

Raleigh and Reston Publishing Service Centers 

